\title{
Synthesis, Characterization and Reactivity of Chromium(VI) Alkylidenes
}

\author{
Pengcheng Wu, Glenn P. A. Yap, and Klaus H. Theopold* \\ Department of Chemistry and Biochemistry \\ University of Delaware, Newark, DE 19711 \\ theopold@udel.edu
}

TOC graphic:

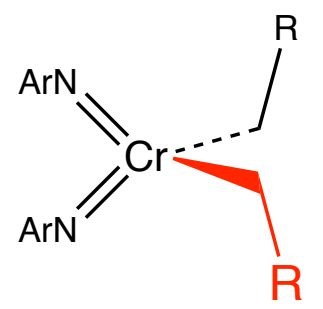

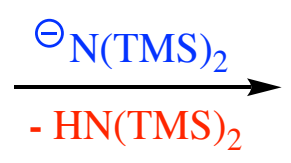

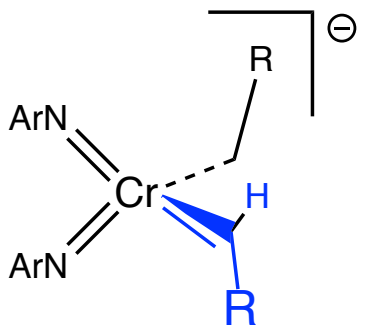

$\mathrm{R}={ }^{t} \mathrm{Bu}, \mathrm{SiMe}_{3}, \mathrm{Ph}$

\begin{abstract}
Chromium(VI) dialkyls are remarkably acidic, yielding a new set of anionic chromium alkylidenes upon deprotonation with $\mathrm{KN}(\mathrm{TMS})_{2}$. We describe the characterization of three anionic chromium alkylidenes of the type $\left[(\mathrm{ArN}){ }_{2} \mathrm{Cr}(=\mathrm{CHR})\left(\mathrm{CH}_{2} \mathrm{R}\right]^{-}\left(\mathrm{R}={ }^{t} \mathrm{Bu}\right.\right.$, $\mathrm{SiMe}_{3}, \mathrm{Ph} ; \mathrm{Ar}=$ 2,6-diisopropylphenyl). $\quad \mathrm{NEt}_{4}\left[(\mathrm{ArN})_{2} \mathrm{Cr}\left(=\mathrm{CHSiMe}_{3}\right)\left(\mathrm{CH}_{2} \mathrm{SiMe}_{3}\right)\right]$ has been structurally characterized by X-ray diffraction. We have also studied the C$\mathrm{H}$ activation of cyclohexane effected by the transient neopentylidene $(\mathrm{ArN})_{2} \mathrm{Cr}\left(=\mathrm{CHCMe}_{3}\right)$. This reaction generated a tri-nuclear chromium(IV) complex, namely ' $\left[\mathrm{Cr}(\mathrm{NAr})_{2}\right]_{3}$ ', as well as the two organic products cyclohexene and neopentane. A probable intermediate in this reaction could be trapped by $\mathrm{PPh}_{3}$ to form $(\mathrm{ArN})_{2} \mathrm{Cr}\left(\mathrm{PPh}_{3}\right)_{2}$. The latter undergoes ligand substitution reactions with ethylene and $\mathrm{CO}$ to produce $\pi$-acid complexes of tetravalent chromium.
\end{abstract}




\section{Introduction}

Transition metal alkylidenes have been a mainstay of organometallic chemistry ever since the initial report of an iconic tantalum neopentylidene by Schrock in $1974 .{ }^{1}$ Their central role in olefin metathesis as well as a host of other transformations has nurtured the continuing interest in this class of compounds..$^{2-5}$ Alkylidenes are well represented amongst the heavy group 6 elements in their hexavalent state, i.e., Mo(VI) and W(VI). ${ }^{6}$ However, analogous chromium alkylidenes are rare, which may be due to the general paucity of organometallic compounds of said metal in its highest formal oxidation state. Coles et al. reported the preparation of $(\mathrm{ArN})_{2} \mathrm{Cr}(=\mathrm{CHCMe}) \mathrm{L}(\mathrm{Ar}=$ 2,6-diisopropylphenyl, $\mathrm{L}=\mathrm{THF}$ and $\mathrm{PMe}_{3}$ ) in $1996,{ }^{7}$ but for various reasons there ensued a hiatus in the exploration of the chemistry of these molecules. Over the years, our own attempts to produce terminal alkylidenes of mid-valent chromium had been cruelly disappointed; ${ }^{8-10}$ therefore we eventually turned our attention to $\mathrm{Cr}(\mathrm{VI})$, the $\mathrm{d}^{0}$ configuration of which stands to benefit so mightily from the $\pi$-donation of the carbene dianion. Recently, we reported the first crystal structures of two chromium alkylidenes, namely $(\mathrm{ArN})_{2} \mathrm{Cr}\left(=\mathrm{CHCMe}_{3}\right)\left(\mathrm{PPh}_{3}\right)$ and $(\mathrm{ArN})_{2} \mathrm{Cr}(=\mathrm{CHSiMe} 3)\left(\mathrm{PPh}_{3}\right)$, as well as some observation regarding their reactivity. ${ }^{11}$ These molecules were generated by $\alpha$-hydrogen abstraction of the corresponding dialkyls. Notably, despite the availability of the corresponding precursors, this method failed to deliver a benzylidene or methylidene. Herein we describe our attempts to broaden the scope of $\mathrm{Cr}(\mathrm{VI})$ alkylidene chemistry, and an exploration of their reactivity with simple hydrocarbons.

\section{Results and Discussion}

\subsection{Synthesis of Alkylidene Anions}

Whereas sterically induced $\alpha$-hydrogen abstraction from transition metal polyalkyls is a well-established path to alkylidenes, there are other synthetic routes to prepare such molecules. For example, deprotonation of suitably activated metal alkyls with strong external base has proven effective. ${ }^{12}$ We wondered whether binding to an electron 
withdrawing $\mathrm{Cr}(\mathrm{VI})$ ion might render alkyl groups unusually acidic. Indeed, we found that $(\mathrm{ArN})_{2} \mathrm{Cr}\left(\mathrm{CH}_{2} \mathrm{SiMe}_{3}\right)_{2}$ could be deprotonated by moderately strong base, i.e. $\mathrm{KN}\left(\mathrm{SiMe}_{3}\right)_{2}\left(\mathrm{pK}_{\mathrm{a}}=26\right.$ in THF $),{ }^{13}$ yielding the anionic alkylidene ate complex $\mathrm{K}\left[(\mathrm{ArN})_{2} \mathrm{Cr}\left(=\mathrm{CHSiMe}_{3}\right)\left(\mathrm{CH}_{2} \mathrm{SiMe}_{3}\right)\right]$ (see Scheme 1).

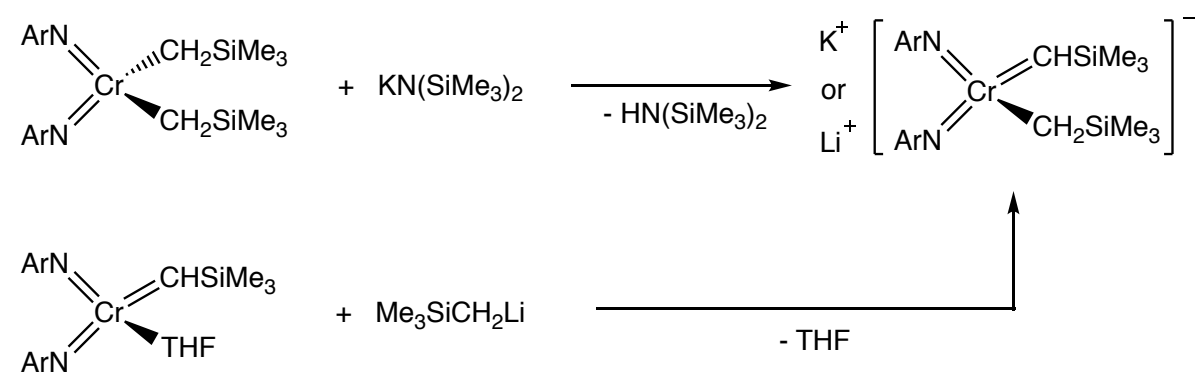

Scheme 1 Synthesis of $\left[(\mathrm{ArN})_{2} \mathrm{Cr}\left(=\mathrm{CHSiMe}_{3}\right)\left(\mathrm{CH}_{2} \mathrm{SiMe}_{3}\right)\right]^{-}$

NMR spectroscopic characterization of the product showed a downfield singlet at 15.15 $\operatorname{ppm}\left({ }^{1} \mathrm{~J}_{\mathrm{CH}}=127.5 \mathrm{~Hz}\right)$ assigned to the alkylidene $\alpha$-hydrogen in the ${ }^{1} \mathrm{H}$ NMR spectrum and a downfield singlet at $295.24 \mathrm{ppm}$ assigned to the alkylidene carbon in the ${ }^{13} \mathrm{C}$ NMR spectrum. These characteristic NMR features are consistent with the presence of an alkylidene ligand. $\mathrm{K}\left[(\mathrm{ArN})_{2} \mathrm{Cr}\left(=\mathrm{CHSiMe}_{3}\right)\left(\mathrm{CH}_{2} \mathrm{SiMe}_{3}\right)\right]$ could be isolated as powder, but it did not crystallize well. However, ion-exchange of the potassium salt with $\mathrm{Et}_{4} \mathrm{NCl}$ (see details in the Experimental Section) readily produced $\mathrm{NEt}_{4}\left[(\mathrm{ArN})_{2} \mathrm{Cr}\left(=\mathrm{CHSiMe}_{3}\right)\left(\mathrm{CH}_{2} \mathrm{SiMe}_{3}\right)\right]$. Single crystals suitable for X-ray diffraction were grown by layering a THF solution of the latter with pentane. The molecular structure of $\mathrm{Et}_{4} \mathrm{~N}\left[(\mathrm{ArN})_{2} \mathrm{Cr}\left(=\mathrm{CHSiMe}_{3}\right)\left(\mathrm{CH}_{2} \mathrm{SiMe}_{3}\right)\right]$ is depicted in Figure 1; it features well separated ions. The alkylidene and alkyl ligands are involved in a positional disorder, which was modeled with a site occupancy ratio of 62/38. The alkylidene anion has a pseudo-tetrahedral coordination geometry $\left(\tau_{4}=0.90\right)^{14}$ with a short $\mathrm{Cr}=\mathrm{C}$ bond (1.791(7) $\AA$ ), which is similar to the alkylidene bond lengths in $(\mathrm{ArN})_{2} \mathrm{Cr}\left(=\mathrm{CHCMe}_{3}\right)\left(\mathrm{PPh}_{3}\right)(1.848(5) \AA)$ and $(\mathrm{ArN})_{2} \mathrm{Cr}\left(=\mathrm{CHSiMe}_{3}\right)\left(\mathrm{PPh}_{3}\right)(1.843(4)$ $\AA$ ). ${ }^{11}$ We suggest that the apparent shortening reflects the lesser steric bulk of the alkyl co-ligand compared to triphenylphosphine. 


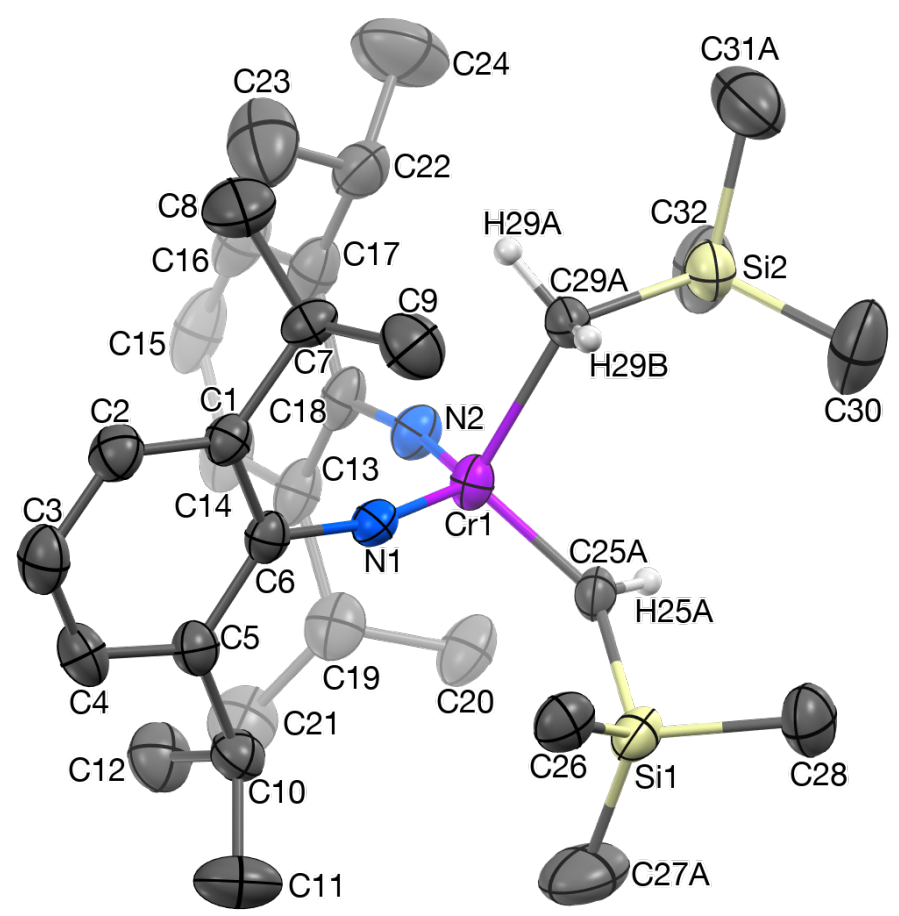

Figure 1 Molecular structure of $\mathrm{Et}_{4} \mathrm{~N}\left[(\mathrm{ArN})_{2} \mathrm{Cr}\left(=\mathrm{CHSiMe}_{3}\right)\left(\mathrm{CH}_{2} \mathrm{SiMe}_{3}\right)\right]$. Ellipsoids are drawn at the $30 \%$ probability level. The $\mathrm{Et}_{4} \mathrm{~N}^{+}$cation and any hydrogen atoms besides the alkylidene hydrogen and the $\alpha$-hydrogens of the alkyl ligand have been omitted for clarity. Selected interatomic distances $[\AA]$ and angles $\left[{ }^{\circ}\right]$ : $\mathrm{Cr} 1-\mathrm{N} 1$, 1.675(4); Cr1 - N2, 1. 670(4); Cr1 - C25, 1.791(7; Cr1 - C29, 2.131(8); N1 - Cr - N2, 120.3(2); C25 - Cr1 - C29, 103.0(4); N1 - Cr1 - C25, 112.1(3); N1 - Cr1 - C29, 104.0(3); N2 - Cr1 - C25, 111.8(3); N2 - Cr1 - C29, 103.2(3).

The alkylidene anion $\left[(\mathrm{ArN})_{2} \mathrm{Cr}\left(=\mathrm{CHSiMe}_{3}\right)\left(\mathrm{CH}_{2} \mathrm{SiMe}_{3}\right)\right]^{-}$could also be prepared independently via a ligand substitution of $(\mathrm{ArN})_{2} \mathrm{Cr}(=\mathrm{CHSiMe})(\mathrm{THF})$, in turn prepared by heating $(\mathrm{ArN})_{2} \mathrm{Cr}\left(\mathrm{CH}_{2} \mathrm{SiMe}_{3}\right)_{2}$ in THF to $80^{\circ} \mathrm{C}$, with $\mathrm{Me}_{3} \mathrm{SiCH}_{2} \mathrm{Li}$ (see Scheme 1). The lithium salt so formed, $\mathrm{Li}\left[(\mathrm{ArN})_{2} \mathrm{Cr}(=\mathrm{CHSiMe} 3)\left(\mathrm{CH}_{2} \mathrm{SiMe}_{3}\right)\right]$, has a ${ }^{1} \mathrm{H}$ NMR spectrum that is identical to that of $\mathrm{K}\left[(\mathrm{ArN})_{2} \mathrm{Cr}\left(=\mathrm{CHSiMe}_{3}\right)\left(\mathrm{CH}_{2} \mathrm{SiMe}_{3}\right)\right]$. This success in making an alkylidene by deprotonating the dialkyl $(\mathrm{ArN})_{2} \mathrm{Cr}\left(\mathrm{CH}_{2} \mathrm{SiMe}_{3}\right)_{2}$ inspired us to extend this method of preparation to compounds that had hitherto not yielded alkylidenes. Thus dibenzyl chromium complex $(\mathrm{ArN})_{2} \mathrm{Cr}\left(\mathrm{CH}_{2} \mathrm{Ph}\right)_{2}$ was also deprotonated successfully by $\mathrm{KN}\left(\mathrm{SiMe}_{3}\right)_{2}$, yielding an 
ionic benzylidene compound, namely $\mathrm{K}\left[(\mathrm{ArN})_{2} \mathrm{Cr}(=\mathrm{CHPh})\left(\mathrm{CH}_{2} \mathrm{Ph}\right)\right]$ (see Scheme 2). After ion-exchange with $\mathrm{Et}_{4} \mathrm{NCl}, \mathrm{Et}_{4} \mathrm{~N}\left[(\mathrm{ArN})_{2} \mathrm{Cr}(=\mathrm{CHPh})\left(\mathrm{CH}_{2} \mathrm{Ph}\right)\right]$ can be crystallized by layering its THF solution with pentane. ${ }^{1} \mathrm{H}$ NMR and ${ }^{13} \mathrm{C}$ NMR spectra were consistent with the formation of the benzylidene ate complex. The peak of the benzylidene hydrogen was found at $13.92 \mathrm{ppm}$ in the ${ }^{1} \mathrm{H}$ NMR spectrum and the resonance at $291.74 \mathrm{ppm}$ in the ${ }^{13} \mathrm{C}$ NMR spectrum was assigned to the benzylidene carbon.

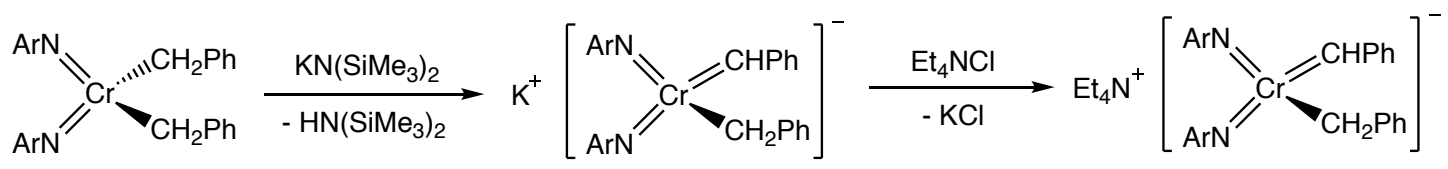

Scheme 2 Synthesis of ionic benzylidene $\left[(\mathrm{ArN})_{2} \mathrm{Cr}(=\mathrm{CHPh})\left(\mathrm{CH}_{2} \mathrm{Ph}\right)\right]^{-}$

Curiously, in our hands attempts to deprotonate $(\mathrm{ArN})_{2} \mathrm{Cr}\left(\mathrm{CH}_{2} \mathrm{CMe}_{3}\right)_{2}$ with $\mathrm{KN}\left(\mathrm{SiMe}_{3}\right)_{2}$ yielded only an intractable mixture of unidentified products rather than the expected $\mathrm{K}\left[(\mathrm{ArN})_{2} \mathrm{Cr}\left(=\mathrm{CHCMe}_{3}\right)\left(\mathrm{CH}_{2} \mathrm{CMe}_{3}\right)\right]$. This was a surprise, as the neutral neopentylidenes, i.e., $(\mathrm{ArN})_{2} \mathrm{Cr}\left(=\mathrm{CHCMe}_{3}\right)(\mathrm{L})\left(\mathrm{L}=\mathrm{THF}, \mathrm{PMe}_{3}, \mathrm{PPh}_{3}\right)$, are the most readily formed. ${ }^{7,11}$ Apparently, this is not for want of stability of the desired ate complex, because $\mathrm{Li}\left[(\mathrm{ArN})_{2} \mathrm{Cr}\left(=\mathrm{CHCMe}_{3}\right)\left(\mathrm{CH}_{2} \mathrm{CMe}_{3}\right)\right]$ was generated successfully via addition of NpLi to a THF solution of $(\mathrm{ArN})_{2} \mathrm{Cr}\left(=\mathrm{CHCMe}_{3}\right)(\mathrm{THF})$ (see Scheme 3$)$. The resonance of its alkylidene hydrogen was found at $13.41 \mathrm{ppm}\left({ }^{1} \mathrm{~J}_{\mathrm{CH}}=128.0 \mathrm{~Hz}\right)$ in the ${ }^{1} \mathrm{H}$ NMR spectrum and the alkylidene carbon has a shift of $306.91 \mathrm{ppm}$ in the ${ }^{13} \mathrm{C}$ NMR spectrum.

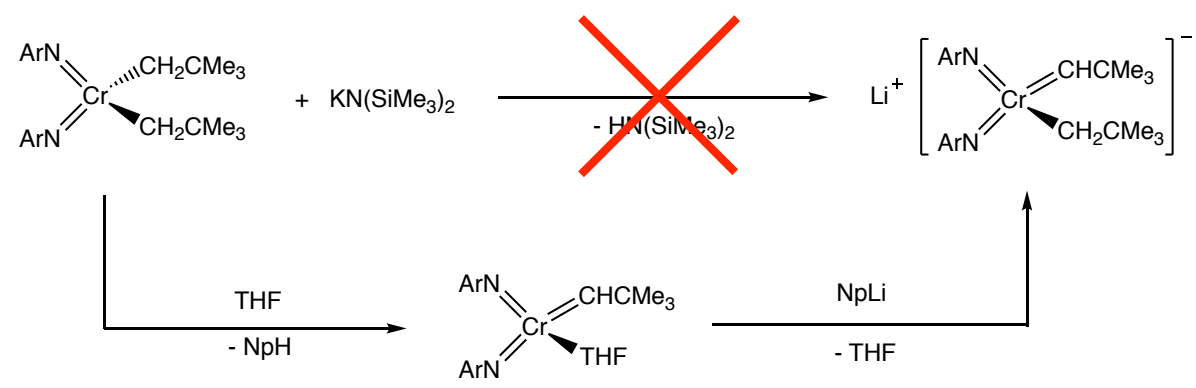

Scheme 3 Synthesis of anionic neopentylidene $\operatorname{Li}\left[(\mathrm{ArN})_{2} \mathrm{Cr}\left(=\mathrm{CHCMe}_{3}\right)\left(\mathrm{CH}_{2} \mathrm{CMe}_{3}\right)\right]$ 
The range of accessible $\mathrm{Cr}(\mathrm{VI})$ alkylidenes thus comprises neopentylidenes, trimethylsilylmethylidenes and benzylidenes, and both neutral and anionic complexes. We have no reason to believe that differently substituted molecules, both at the $\alpha$ carbon and the chromium, should be out of synthetic reach. Our continuing exploration may produce further examples.

\subsection{C-H activation with alkylidenes}

The transient neopentylidene produced by elimination of neopentane from $(\mathrm{ArN})_{2} \mathrm{Cr}\left(\mathrm{CH}_{2} \mathrm{CMe}_{3}\right)_{2}$ was reported to activate the $\mathrm{C}$-D bonds of $\mathrm{C}_{6} \mathrm{D}_{6} \cdot{ }^{7}$ In the same vein, we found that it also reacts with saturated hydrocarbons. Thus, prolonged exposure of $(\mathrm{ArN})_{2} \mathrm{Cr}\left(\mathrm{CH}_{2} \mathrm{CMe}_{3}\right)_{2}$ to $\mathrm{SiMe}_{4}$ first produced $(\mathrm{ArN})_{2} \mathrm{Cr}\left(\mathrm{CH}_{2} \mathrm{CMe}_{3}\right)\left(\mathrm{CH}_{2} \mathrm{SiMe}_{3}\right)$ and finally $(\mathrm{ArN})_{2} \mathrm{Cr}\left(\mathrm{CH}_{2} \mathrm{SiMe}_{3}\right)_{2} .{ }^{11}$ These alkyls are of course particular in not being subject to facile $\beta$-hydrogen elimination. In order to find out how a reaction with hydrocarbons containing $\beta$-hydrogen would evolve, we investigated the reaction of $(\mathrm{ArN})_{2} \mathrm{Cr}\left(\mathrm{CH}_{2} \mathrm{CMe}_{3}\right)_{2}$ with cyclohexane. The reaction proceeds at room temperature and yields the products shown in Scheme 4.
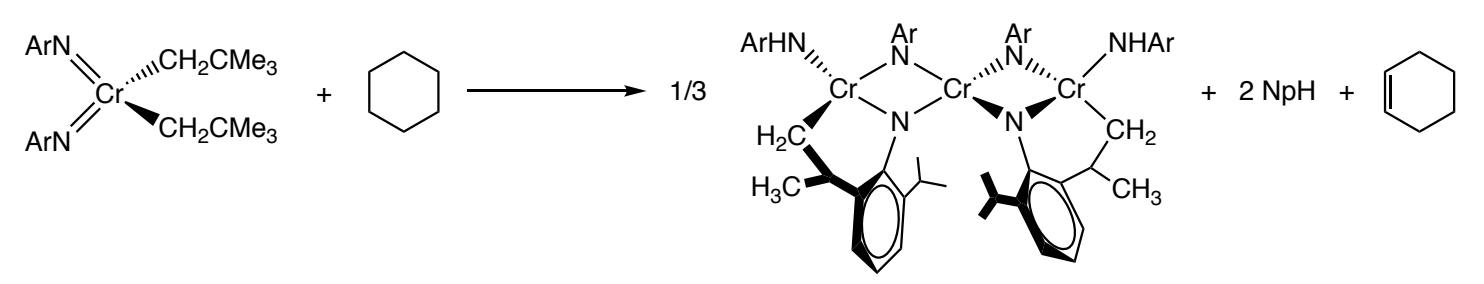

Scheme 4 C-H bond activation of cyclohexane initiated by $(\mathrm{ArN})_{2} \mathrm{Cr}\left(\mathrm{CH}_{2} \mathrm{CMe}_{3}\right)_{2}$

Over the course of 3 days, the green color of cyclohexane solutions of $(\mathrm{ArN})_{2} \mathrm{Cr}\left(\mathrm{CH}_{2} \mathrm{CMe}_{3}\right)_{2}$ changed to a reddish purple. Standard work-up of such a solution yielded crystals of the metal containing product, which was structurally characterized by X-ray diffraction. Its molecular structure is depicted in Figure 2; the molecule is formally a trimer of the $\mathrm{Cr}(\mathrm{NAr})_{2}$ fragment (for simplicity's sake it will therefore be referred to as ' $\left[\mathrm{Cr}(\mathrm{NAr})_{2}\right]_{3}$ '), albeit having undergone a tautomerization 
involving transfer of an isopropyl hydrogen atom to an imido nitrogen.

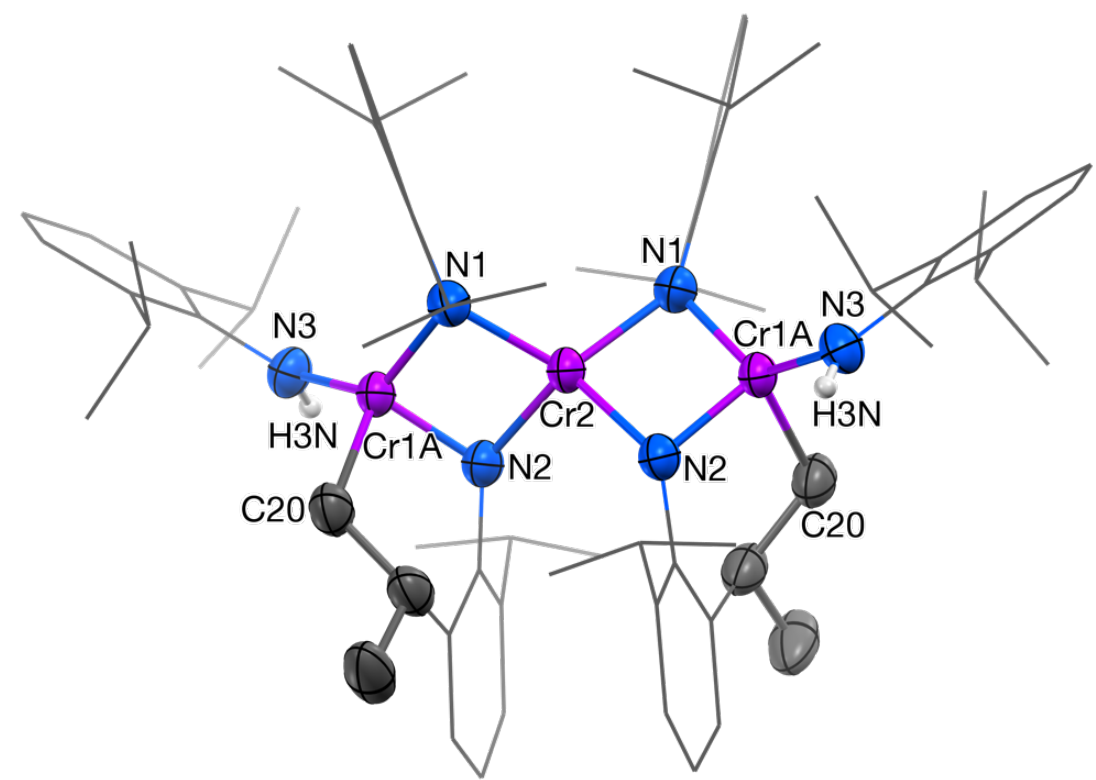

Figure 2. The molecular structure of trinuclear ' $\left[\mathrm{Cr}(\mathrm{NAr})_{2}\right]_{3}$ '. Ellipsoids are drawn at the $30 \%$ probability level. Hydrogen atoms besides the amido hydrogens $(\mathrm{H} 3 \mathrm{~N})$ have been omitted for clarity. Aromatic rings and isopropyl groups are drawn in wireframe representation for clarity. Selected interatomic distances $[\AA]$ and angles ${ }^{\circ}{ }^{\circ}$ : $\mathrm{Cr} 1 \mathrm{~A}-\mathrm{Cr} 2,2.5440(4) ; \mathrm{Cr} 1 \mathrm{~A}-\mathrm{N} 1,1.792(2) ; \mathrm{Cr} 1 \mathrm{~A}-\mathrm{N} 2,1.763(2)$; Cr1A - N3, 1.836(2); Cr1A-C20, 2.040(3); Cr2 - N1, 1.862(2); Cr2 - N2, 1.889(2); N1-Cr1A - N2, 94.92(10); N1 - Cr1A - N3, 128.78(11); N2 - Cr1A - N3, 109. 02(12); C20 Cr1A - N1, 109.54(13); C20 - Cr1A - N2, 91.96(13); C20 - Cr1A - N3, 113.95 (12); $\mathrm{N} 1$ - Cr2 - N1, 117.12(14); N1 - Cr2 - N2, 132.89(12); N2 - Cr2 - N2, 102(08(13).

The three chromium centers of the trinuclear complex form a roughly linear arrangement $\left(\mathrm{Cr} 1 \mathrm{~A}-\mathrm{Cr} 2-\mathrm{Cr} 1 \mathrm{~A}, 171.43(3)^{\circ}\right)$ and all three metal atoms have pseudotetrahedral coordination environments $\left(\mathrm{Cr} 1 \mathrm{~A}: \tau_{4}=0.83, \mathrm{Cr} 2: \tau_{4}=0.67\right) .{ }^{14}$ While the resulting Cr-Cr distances are short (Cr1A - Cr2, 2. 5440(4) $\AA$ ), the structure does not provide any corroborating evidence for significant metal-metal bonding. Notably, though, the acquisition of sharp ${ }^{1} \mathrm{H}$ and ${ }^{13} \mathrm{C}$ NMR spectra indicates that ' $\left[\mathrm{Cr}(\mathrm{NAr})_{2}\right]_{3}$ ' - best described as all Cr(IV) $\left(\mathrm{d}^{2}\right)$ - is diamagnetic. The amido hydrogen $\mathrm{H} 3 \mathrm{~N}$ was assigned on N3 due to the long distance between Cr1 A and N3 (1.836(2) $\AA$ ), which is obviously longer than a terminal $\mathrm{Cr}=\mathrm{N}$ imido bond (around $1.64 \AA$ ) ${ }^{15-20}$ The 
relatively small angle of $\mathrm{Cr} 1 \mathrm{~A}-\mathrm{N} 3-\mathrm{C}_{\mathrm{ipso}} \mathrm{Ar}\left(139.1(2)^{\circ}\right) \quad$ is also consistent with the assignment as an amido ligand. A band at $3340 \mathrm{~cm}^{-1}$ in the IR spectrum is the requisite $\mathrm{N}-\mathrm{H}$ stretching vibration. Besides, LIFDI-MS data also agree with the molecular formula of $\mathrm{Cr}_{3} \mathrm{C}_{72} \mathrm{H}_{102} \mathrm{~N}_{6}$. As an aside, the solid state structure of ' $\left[\mathrm{Cr}(\mathrm{NAr})_{2}\right]_{3}$ ' exhibits a case of intramolecular $\pi$-stacking between the two aromatic rings with the $\mathrm{C}-\mathrm{H}$ activated isopropyl groups. The distance between the centroids of these two rings is $3.853 \AA$ with a dihedral angle of $7.72^{\circ}$. The interaction between the two rings may be described as an example of intramolecular parallel offset $\pi$ stacking. ${ }^{21-22}$

To fully understand the mechanism of formation of ' $\left[\mathrm{Cr}(\mathrm{NAr})_{2}\right]_{3}$ ', the organic byproducts of this reaction needed to be identified. To this end, the reaction was set up in a sealed and degassed glass vessel. ${ }^{1} \mathrm{H}$ NMR analysis of the volatile products (including the large excess of cyclohexane) revealed the formation of neopentane and cyclohexene in the ratio of 2.06:1. Based on these observations, Scheme 5 shows a proposed mechanism of the reaction of $(\mathrm{ArN})_{2} \mathrm{Cr}\left(\mathrm{CH}_{2} \mathrm{CMe}_{3}\right)_{2}$ with cyclohexane.<smiles>CCC(=N)CC</smiles>

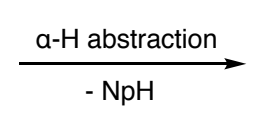<smiles>CC=C(CC)N=[W]</smiles>

C-H activation<smiles>[CH2+]C1CCCCC1</smiles>

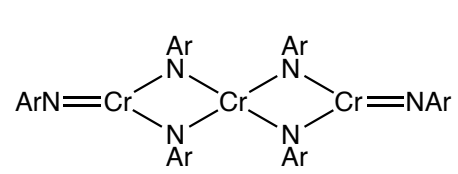

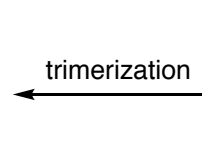

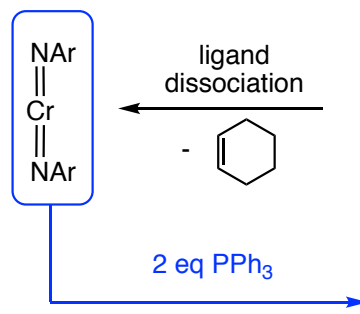<smiles>CCOC(=N)CC</smiles>
- $\mathrm{NpH} \mid \beta-\mathrm{H}$ elimination $\downarrow$ reductive elimination<smiles>C=C</smiles>

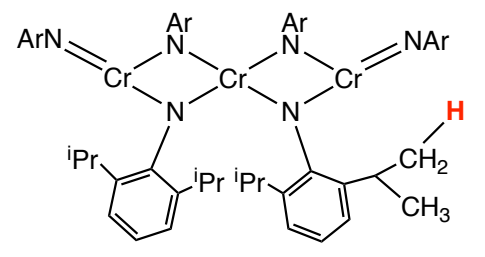<smiles>C[13CH2]</smiles>

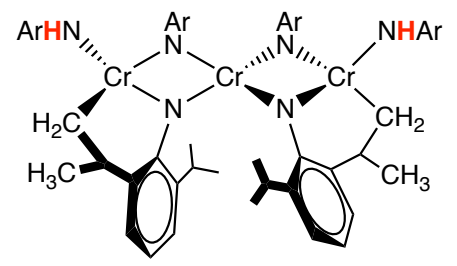


Scheme 5 A proposed mechanism for the formation of ' $\left[\mathrm{Cr}(\mathrm{NAr})_{2}\right]_{3}$ '

Chromium dialkyl $(\mathrm{ArN})_{2} \mathrm{Cr}(\mathrm{Np})_{2}$ undergoes $\alpha$-hydrogen abstraction to yield neopentane and a coordinatively unsaturated neopentylidene, which then reacts with cyclohexane to produce a mixed chromium dialkyl, i.e., $(\mathrm{ArN})_{2} \mathrm{Cr}(\mathrm{Np})(\mathrm{Cy})$. Due to the $\beta$-hydrogen on the cyclohexyl group, this mixed alkyl intermediate is unstable and presumably decomposes via $\beta$-hydrogen elimination, yielding cyclohexene, and followed by reductive elimination of the second equivalent of neopentane to leave the two-coordinate $\mathrm{Cr}(\mathrm{IV})$ intermediate $\mathrm{Cr}(\mathrm{NAr})_{2}$. Due to its coordinative unsaturation, the latter is likely to oligomerize; indeed, it apparently trimerizes. In the last step, the terminal imido reacts rapidly with a $\mathrm{C}-\mathrm{H}$ bond of isopropyl methyl, yielding the final product, ' $\left[\mathrm{Cr}(\mathrm{NAr})_{2}\right]_{3}$ '.

In support of this proposed mechanism, and particularly the intermediate formation of $\mathrm{Cr}^{\mathrm{IV}}(\mathrm{NAr})_{2}$, the latter can be trapped by $\mathrm{PPh}_{3}$ to form a stable complex, i.e. $(\mathrm{ArN})_{2} \mathrm{Cr}\left(\mathrm{PPh}_{3}\right)_{2}$. When $(\mathrm{ArN})_{2} \mathrm{Cr}(\mathrm{Np})_{2}$ and two equivalents of $\mathrm{PPh}_{3}$ were dissolved in cyclohexane and stirred at room temperature for three days, the color of the solution changed from green to brown. The molecular structure of the product, $(\mathrm{ArN})_{2} \mathrm{Cr}\left(\mathrm{PPh}_{3}\right)_{2}$, has been determined by X-ray diffraction and it is depicted in Figure 3. $(\mathrm{ArN})_{2} \mathrm{Cr}\left(\mathrm{PPh}_{3}\right)_{2}$ features pseudo-tetrahedral coordination geometry $\left(\tau_{4}=0.82\right)^{14}$ about chromium and crystallographic $\mathrm{C}_{2}$ symmetry with the largest bond angle, i.e. N1-Cr1$\mathrm{N} 1,133.66(7)^{\mathrm{o}}$, being significantly opened up compared to bis(imido) chromium dialkyls and even alkylidenes. ${ }^{15,17-19}$ The imido bonds of $(\mathrm{ArN})_{2} \mathrm{Cr}\left(\mathrm{PPh}_{3}\right)_{2}(\mathrm{Cr} 1-\mathrm{N} 1$, 1.6934(10) A) are slightly longer than those of those bis(imido) chromium(VI) complexes, consistent with the lower formal oxidation state of chromium. As indicated by the sharp NMR spectra $\left({ }^{1} \mathrm{H}\right.$ NMR, ${ }^{13} \mathrm{C}$ NMR, and ${ }^{31} \mathrm{P}$ NMR), this $\mathrm{Cr}(\mathrm{IV})$ complex is also diamagnetic.

It is interesting to note that the above trapping reaction differs in its outcome from the thermal decomposition of $(\mathrm{ArN})_{2} \mathrm{Cr}(\mathrm{Np})_{2}$ in the presence of $\mathrm{PPh}_{3}$, when carried out in THF. The latter, of course, yielded $(\mathrm{ArN})_{2} \mathrm{Cr}\left(=\mathrm{CHCMe}_{3}\right)\left(\mathrm{PPh}_{3}\right) .{ }^{11}$ This observation suggests that the 3-coordinate alkylidene intermediate, $(\mathrm{ArN})_{2} \mathrm{Cr}\left(=\mathrm{CHCMe}_{3}\right)$, is so 
exquisitely reactive that it foregoes any selectivity, binding the first molecule it encounters - be it THF or cyclohexane.

$(\mathrm{ArN})_{2} \mathrm{Cr}\left(\mathrm{PPh}_{3}\right)_{2}$ can also be prepared independently by reduction of $(\mathrm{ArN})_{2} \mathrm{CrCl}_{2}$ with $\mathrm{Mg}$ in the presence of $\mathrm{PPh}_{3}$, a synthetic route that had previously been used to prepare $(\mathrm{ArN})_{2} \mathrm{Cr}(\mathrm{L})_{2}$ with $\mathrm{L}=\mathrm{PMe}_{3}, \mathrm{PMe}_{2} \mathrm{Ph}^{23}$ Despite the $\mathrm{d}^{2}$ configuration in approximately tetrahedral coordination environment, all complexes of this type (see also below) are diamagnetic. By way of explanation, one may note the isolobality of imido and cyclopentadienyl donors, or - more pertinently - the bent $(\mathrm{RN})_{2} \mathrm{M}$ and $\mathrm{Cp}{ }_{2} \mathrm{M}$ fragments. ${ }^{24}$ The frontier orbitals of the latter have been extensively analyzed, ${ }^{25}$ and by extension this analysis is consistent with a single d-orbital of lowest energy for all $(\mathrm{ArN})_{2} \mathrm{Cr}^{\mathrm{IV}} \mathrm{L}_{2}$. While there are not many examples of $\mathrm{Cp}_{2} \mathrm{Cr}^{\mathrm{IV}}$ compounds, the representative $\left[\mathrm{Me}_{4} \mathrm{C}_{2}\left(\eta_{5}-\mathrm{C}_{5} \mathrm{H}_{4}\right)\left(\eta_{5}-\mathrm{C}_{5} \mathrm{H}_{3} \mathrm{~B}\left(\mathrm{C}_{6} \mathrm{~F}_{5}\right)_{3}\right)\right] \mathrm{Cr}(\mathrm{CN}) \mathrm{CNXyl}$ is diamagnetic, as expected. ${ }^{26}$

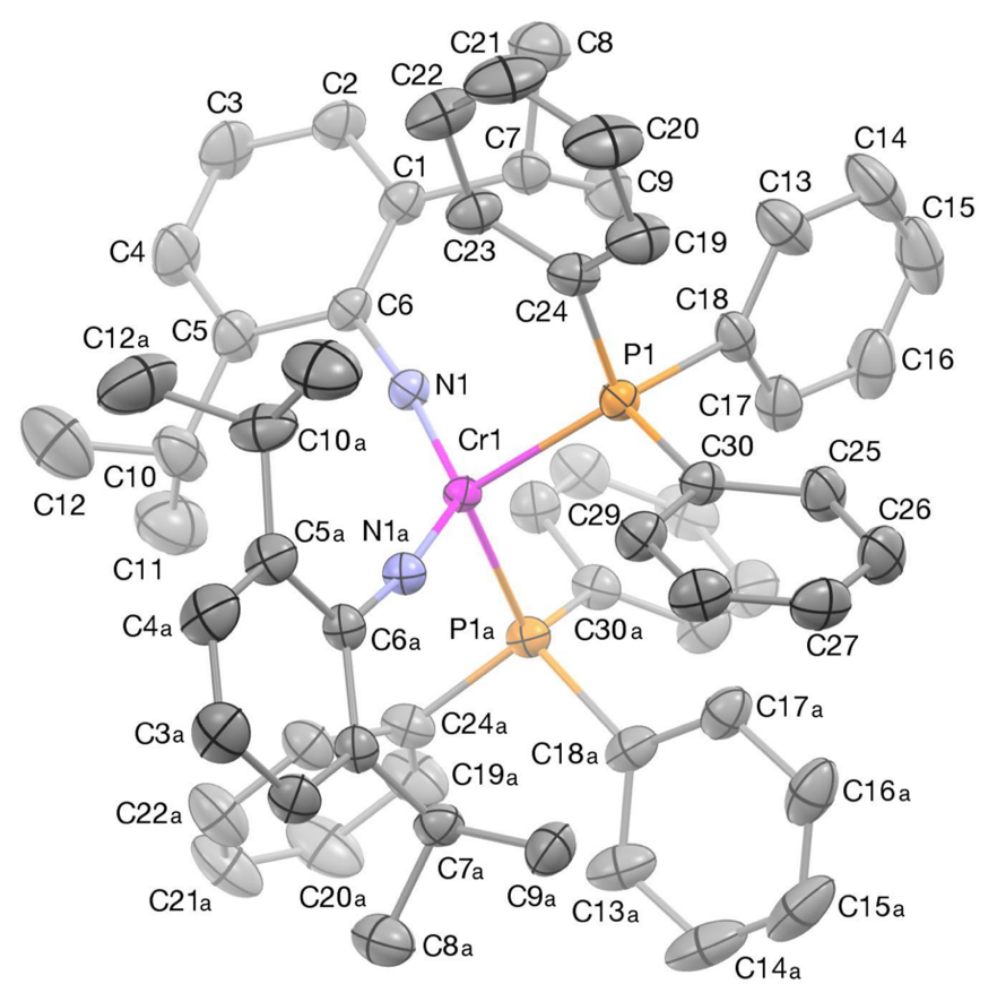

Figure 3. The molecular structure of $(\mathrm{ArN})_{2} \mathrm{Cr}\left(\mathrm{PPh}_{3}\right)_{2}$. Ellipsoids are drawn at the $30 \%$ probability level. Hydrogen atoms have been omitted for clarity. Selected interatomic distances $[\AA]$ and angles $\left[^{\circ}\right]$ : $\mathrm{Cr} 1-\mathrm{N} 1,1.6934(10)$; Cr1 - P1, 2.3210(3); N1 - Cr - N1a, 133.66(7); N1 - Cr - P1, 102.60(3); N1 - Cr - P1a, 103.42(3); P1 - Cr - P1a, 
$110.217(18)$

\subsection{Ligand Substitution of $(\mathrm{ArN})_{2} \mathrm{Cr}\left(\mathrm{PPh}_{3}\right)_{2}$}

Upon exposure to $\pi$-acid ligands, such as ethylene and carbon monoxide, one phosphine ligand of $(\mathrm{ArN})_{2} \mathrm{Cr}\left(\mathrm{PPh}_{3}\right)_{2}$ can be replaced, yielding $(\mathrm{ArN})_{2} \mathrm{Cr}\left(\mathrm{PPh}_{3}\right)\left(\mathrm{C}_{2} \mathrm{H}_{4}\right)$ and $(\mathrm{ArN})_{2} \mathrm{Cr}\left(\mathrm{PPh}_{3}\right)(\mathrm{CO})$, respectively, in situ. (see Scheme 6).

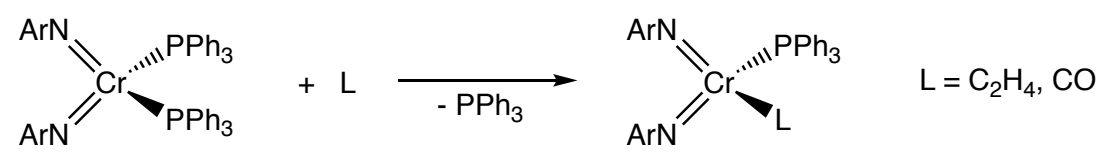

Scheme 6 Ligand substitutions of $(\mathrm{ArN})_{2} \mathrm{Cr}\left(\mathrm{PPh}_{3}\right)_{2}$ with ethylene or $\mathrm{CO}$

The ethylene adduct was characterized in solution, under ethylene (1atm), with multinuclear NMR spectroscopy, 2D-NMR HSQC, and LIFDI-MS. Notably, the ethylene ligand gives rise to two distinct ${ }^{1} \mathrm{H}$ NMR resonances, indicating that its rotation is slow on the NMR time scale. Upon removal of the ethylene gas, the ethylene adduct reverted to $(\mathrm{ArN})_{2} \mathrm{Cr}\left(\mathrm{PPh}_{3}\right)_{2}$ due to the presence of free phosphine in the solution. $(\mathrm{ArN})_{2} \mathrm{Cr}\left(\mathrm{PPh}_{3}\right)(\mathrm{CO})$, while initially formed and spectroscopically characterized ( $v_{\mathrm{C}-\mathrm{O}}$ $=1932 \mathrm{~cm}^{-1}$ ), proved unstable at room temperature. It slowly decomposed to $(\mathrm{ArN}) \mathrm{Cr}\left(\mathrm{PPh}_{3}\right)(\mathrm{CO})_{3}$, yielding an equivalent of the aryl isocyanate $\mathrm{ArNCO}$ as the organic byproduct (see Scheme 7).

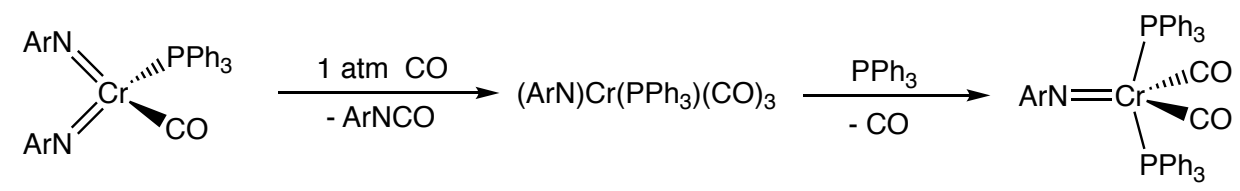

Scheme 7 Decomposition of $(\mathrm{ArN})_{2} \mathrm{Cr}\left(\mathrm{PPh}_{3}\right)(\mathrm{CO})$

The formation of $(\mathrm{ArN}) \mathrm{Cr}\left(\mathrm{PPh}_{3}\right)(\mathrm{CO})_{3}$ was supported by NMR spectroscopy and LIFDI-MS. ArNCO was identified by comparison of NMR spectra $\left({ }^{1} \mathrm{H},{ }^{13} \mathrm{C}\right)$ of the reaction solution with those of authentic ArNCO. Eventually, $(\mathrm{ArN}) \mathrm{Cr}\left(\mathrm{PPh}_{3}\right)(\mathrm{CO})_{3}$ reacted further with free phosphine and slowly transformed into $(\mathrm{ArN}) \mathrm{Cr}\left(\mathrm{PPh}_{3}\right)_{2}(\mathrm{CO})_{2}$. The crystal structure of this final product, a terminal imido complex of divalent chromium, was determined by X-ray diffraction (see the Supplementary Information). 


\section{Conclusions}

We have found that $\mathrm{Cr}(\mathrm{VI})$ dialkyls of the type $(\mathrm{ArN})_{2} \mathrm{Cr}\left(\mathrm{CH}_{2} \mathrm{R}\right)_{2}$ are relatively acidic and can be readily deprotonated with $\mathrm{KN}(\mathrm{TMS})_{2}$. In this way we have prepared and characterized multiple anionic chromium alkylidenes, thereby extending the scope of known chromium alkylidenes to now include a benzylidene. The coordinatively unsaturated neopentylidene intermediate $(\mathrm{ArN})_{2} \mathrm{Cr}=\mathrm{CHCMe}_{3}$ is highly reactive towards hydrocarbons such as cyclohexane. The inorganic product of this reaction, the trinuclear $\mathrm{Cr}^{\mathrm{IV}}$ complex ' $\left[\mathrm{Cr}(\mathrm{NAr})_{2}\right]_{3}$ ' has been structurally characterized and we have proposed a mechanism to account for the formation of this compound and the organic products of the reaction. A probable intermediate of the reaction was trapped by $\mathrm{PPh}_{3}$ to form an isolable phosphine adduct. The latter showed ligand substitution reactivity with ethylene and carbon monoxide.

\section{Experimental Section}

General Considerations. All manipulations were carried out with standard Schlenk, vacuum line, and glovebox techniques. Pentane, diethyl ether, toluene and tetrahydrofuran were dried by passing through activated alumina and were degassed prior to use. THF- $\mathrm{d}_{8}$ and $\mathrm{C}_{6} \mathrm{D}_{6}$ were purchased from Cambridge Isotopes Laboratory, dried with sodium and stored under vacuum over $\mathrm{Na} / \mathrm{K}$ alloy. Grignard reagents, $\mathrm{PPh}_{3}$, $\mathrm{KN}\left(\mathrm{SiMe}_{3}\right)_{2}, \mathrm{Et}_{4} \mathrm{NCl}$ and cyclohexane were purchased from Sigma Aldrich. Cyclohexane was dried with molecular sieves and stored in an inert atmosphere glove box. $\quad(\mathrm{ArN})_{2} \mathrm{CrCl}_{2},{ }^{16} \quad(\mathrm{ArN})_{2} \mathrm{Cr}\left(\mathrm{CH}_{2} \mathrm{Ph}\right)_{2},{ }^{27} \quad(\mathrm{ArN})_{2} \mathrm{Cr}\left(\mathrm{CH}_{2} \mathrm{CMe}_{3}\right)_{2},{ }^{7} \quad$ and $(\mathrm{ArN})_{2} \mathrm{Cr}\left(\mathrm{CH}_{2} \mathrm{SiMe}_{3}\right)_{2}{ }^{11}(\mathrm{Ar}=2,6$-diisopropylpenyl) were prepared according to the literature procedures.

${ }^{1} \mathrm{H}$ NMR spectra were taken on a Bruker AVIII-400 spectrometer and were referenced to the residual protons of the solvent $\left(\mathrm{C}_{6} \mathrm{D}_{5} \mathrm{H}=7.16 \mathrm{ppm}, \mathrm{THF}-\mathrm{d}_{7}=3.58 \mathrm{ppm}\right.$ and 1.72 ppm). ${ }^{13} \mathrm{C}$ NMR spectra were taken on a Bruker AVIII-400 spectrometer or a Bruker AVIII600 spectrometer and were referenced to the naturally abundant ${ }^{13} \mathrm{C}$ of the solvent 
$\left(\mathrm{C}_{6} \mathrm{D}_{6}=128.06 \mathrm{ppm}\right.$, THF- $\mathrm{d}_{8}=67.21 \mathrm{ppm}$ and $\left.25.31 \mathrm{ppm}\right)$. FT-IR spectra were obtained using a Nicolet Magna-IR 560 spectrometer with a resolution of $4 \mathrm{~cm}^{-1}$. UVvis spectra were obtained using a SILVER-Nova-TEC-X2 equipped with SL1-LED, which was purchased from StellarNet Inc. X-ray crystallographic studies were conducted in the X-ray Crystallographic Laboratory at the University of Delaware. Elemental analyses were obtained from Robertson Microlit, Ledgewood, NJ. LIFDIMS were obtained using a Waters GCT Premier high-resolution time-of-flight mass spectrometer by liquid injection field desorption ionization (LIFDI-MS). ${ }^{28}$

\section{$\mathrm{K}\left[(\mathrm{ArN})_{2} \mathrm{Cr}\left(=\mathrm{CHSiMe}_{3}\right)\left(\mathrm{CH}_{2} \mathrm{SiMe}_{3}\right)\right], \mathrm{Et}_{4} \mathrm{~N}\left[(\mathrm{ArN})_{2} \mathrm{Cr}\left(=\mathrm{CHSiMe}_{3}\right)\left(\mathrm{CH}_{2} \mathrm{SiMe}_{3}\right)\right]$ :} $(\mathrm{ArN})_{2} \mathrm{Cr}\left(\mathrm{CH}_{2} \mathrm{SiMe}_{3}\right)_{2}(0.230 \mathrm{~g}, 0.400 \mathrm{mmol})$ was dissolved in $50 \mathrm{~mL}$ THF giving a green solution. 1 equiv. of $\mathrm{KN}\left(\mathrm{SiMe}_{3}\right)_{2}(0.080 \mathrm{~g}, 0.400 \mathrm{mmol})$ was added into the green solution at room temperature. The solution was stirred for 1 hour during which time the color changed to brown and then finally to red. All volatile solvents were removed in vacuum. The residue was washed with pentane and filtered to give the product as powder. Yield: $0.222 \mathrm{~g}, 91 \%$. It was then dissolved in THF, giving a bright red solution. 1 equiv. of $\mathrm{Et}_{4} \mathrm{NCl}(0.060 \mathrm{~g}, 0.361 \mathrm{mmol})$ was added to the red solution at room temperature. The solution was stirred for 4 hours during which time no color change was observed. The solvent was removed in vacuum and the residue was redissolved in a small amount of THF. $\mathrm{KCl}$ was removed by filtering the THF solution. Crystalline product was obtained from recrystallization by layering the THF solution with pentane (volume ratio $=1: 2$ ) at $-30^{\circ} \mathrm{C}$. Characterization for $\mathrm{K}\left[(\mathrm{ArN})_{2} \mathrm{Cr}\left(=\mathrm{CHSiMe}_{3}\right)\left(\mathrm{CH}_{2} \mathrm{SiMe}_{3}\right)\right]:{ }^{1} \mathrm{H} \mathrm{NMR}\left(400 \mathrm{MHz}, \mathrm{THF}-\mathrm{d}_{8}\right): \delta 15.15\left(\mathrm{~s},{ }^{1} \mathrm{~J}_{\mathrm{CH}}\right.$ $=127.5 \mathrm{~Hz}, 1 \mathrm{H}, \mathrm{CHSiMe}$ ), 6.73 (d, $2 \mathrm{H}, \mathrm{H}_{\text {meta }}$ of $\left.\mathrm{ArN}\right), 6.67$ (d, $2 \mathrm{H}, \mathrm{H}_{\text {meta }}$ of ArN), 6.48 (t, $1 \mathrm{H}, \mathrm{H}_{\text {para }}$ of $\left.\mathrm{ArN}\right), 6.39$ (t, $1 \mathrm{H}, \mathrm{H}_{\text {para }}$ of $\mathrm{ArN}$ ), 4.13 (sept, $2 \mathrm{H}, \mathrm{CHMe}$ ), 3.88 (sept, $2 \mathrm{H}, \mathrm{CHMe}$ ), 1.15 (d, 6H, CHMe $), 1.13$ (d, 6H, CHMe $), 1.01$ (d, $6 \mathrm{H}$, $\mathrm{CHMe}$ ), 0.84 (d, $6 \mathrm{H}, \mathrm{CHMe}$ ), 0.18 (s, 2 H, $\mathrm{CH}_{2} \mathrm{SiMe}_{3}$ ), 0.03 (s, $9 \mathrm{H},=\mathrm{CHSiMe}$ ), 0.09 (s, $\left.9 \mathrm{H}, \mathrm{CH}_{2} \mathrm{SiMe} e_{3}\right) \mathrm{ppm} .{ }^{13} \mathrm{C}\left({ }^{1} \mathrm{H}\right) \mathrm{NMR}\left(150 \mathrm{MHz}, \mathrm{THF}-\mathrm{d}_{8}\right) \delta 295.24$ (CHSiMe $), 158.66$ ( $\left.\mathrm{C}_{\text {ipso }}\right), 158.55$ ( $\left.\mathrm{C}_{\text {ipso }}\right), 140.88$ ( $\left.\mathrm{C}_{\text {ortho }}\right), 139.65\left(\mathrm{C}_{\text {ortho }}\right), 120.44$ $\left(\mathrm{C}_{\text {para }}\right), 120.33\left(\mathrm{C}_{\text {para }}\right), 118.36\left(\mathrm{C}_{\text {meta }}\right), 117.24\left(\mathrm{C}_{\text {meta }}\right), 27.58\left(\mathrm{CHMe}_{2}\right), 27.07$ 
(CHMe 2$), 23.71\left(\mathrm{CHMe}_{2}\right), 23.54(\mathrm{CHMe}), 22.83(\mathrm{CHMe}), 22.43(\mathrm{CHMe}), 14.11$

$\left(\mathrm{CH}_{2} \mathrm{SiMe}_{3}\right), 2.28$ (=CHSiMe $), 2.13\left(\mathrm{CH}_{2} \mathrm{SiMe}\right)$ ppm. IR $\left(\mathrm{KBr}, \mathrm{cm}^{-1}\right): 3052(\mathrm{w})$, 2959 (s), 2866 (w), $1576(\mathrm{w}), 1460$ (w), 1413 (m), 1381 (w), 1359 (w), $1331(\mathrm{~s}), 1282$

(s), $1244(\mathrm{~m}), 1216(\mathrm{w}), 1096(\mathrm{w}), 991(\mathrm{w}), 942(\mathrm{w}), 906(\mathrm{w}), 847(\mathrm{~s}), 795(\mathrm{w}), 754$ $(\mathrm{m}), 718(\mathrm{w}), 680(\mathrm{w}) . \mathrm{UV}$-vis $(\mathrm{THF}): \lambda_{\max }(\varepsilon)=250\left(2.3 * 10^{5}\right), 311\left(1.1 * 10^{5}\right), 430$ $\left(3.9 * 10^{4}\right)\left(\mathrm{M}^{-1} \mathrm{~cm}^{-1}\right)$. Anal. Calcd. for $\mathrm{C}_{32} \mathrm{H}_{55} \mathrm{CrN}_{2} \mathrm{Si}_{2} \mathrm{~K}: \mathrm{C}, 62.49 ; \mathrm{H}, 9.01 ; \mathrm{N}, 4.55$. Found: C, 59.14; H, 8.72; N, 4.24. M.P.: $235^{\circ} \mathrm{C}$.

Characterization for $\mathrm{Et}_{4} \mathrm{~N}\left[(\mathrm{ArN})_{2} \mathrm{Cr}\left(=\mathrm{CHSiMe}_{3}\right)\left(\mathrm{CH}_{2} \mathrm{SiMe}_{3}\right)\right]:{ }^{1} \mathrm{H} \mathrm{NMR}(400 \mathrm{MHz}$, THF-d $\left.\mathrm{d}_{8}\right): \delta 15.17\left(\mathrm{~s},{ }^{1} \mathrm{~J}_{\mathrm{CH}}=126.5 \mathrm{~Hz}, 1 \mathrm{H}, \mathrm{CHSiMe}\right), 6.75\left(\mathrm{~d}, 2 \mathrm{H}, \mathrm{H}_{\text {meta }}\right.$ of ArN), $6.69\left(\mathrm{~d}, 2 \mathrm{H}, \mathrm{H}_{\text {meta }}\right.$ of $\left.\mathrm{ArN}\right), 6.49\left(\mathrm{t}, 1 \mathrm{H}, \mathrm{H}_{\text {para }}\right.$ of $\left.\mathrm{ArN}\right), 6.40\left(\mathrm{t}, 1 \mathrm{H}, \mathrm{H}_{\text {para }}\right.$ of $\left.\mathrm{ArN}\right)$, 4.13 (sept, $2 \mathrm{H}, \mathrm{CHMe}$ ), 3.89 (sept, $2 \mathrm{H}, \mathrm{CHMe}$ ), 3.24 (q, $8 \mathrm{H}, \mathrm{CH}_{2} \mathrm{CH}_{3}$ ), 1.25 (br, $12 \mathrm{H}, \mathrm{CH}_{2} \mathrm{CH}_{3}$ ), 1.16 (d, 6H, CHMe $), 1.15$ (d, 6H, CHMe $), 1.03$ (d, $6 \mathrm{H}, \mathrm{CHMe}$ ), 0.85 (d, $6 \mathrm{H}, \mathrm{CHMe}$ ), 0.19 (s, $\left.2 \mathrm{H}, \mathrm{CH}_{2} \mathrm{SiMe}_{3}\right), 0.05$ (s, $9 \mathrm{H},=\mathrm{CHSiMe}$ ), -0.08 (s, 9 $\left.\left.\mathrm{H}, \mathrm{CH}_{2} \mathrm{SiMe}\right)_{3}\right) \mathrm{ppm} .{ }^{13} \mathrm{C}\left\{{ }^{1} \mathrm{H}\right\} \mathrm{NMR}\left(150 \mathrm{MHz}, \mathrm{THF}-\mathrm{d}_{8}\right) \delta 296.17\left(\mathrm{CHSiMe}_{3}\right), 159.50$ $\left(\mathrm{C}_{\text {ipso }}\right), 159.39\left(\mathrm{C}_{\text {ipso }}\right), 141.68\left(\mathrm{C}_{\text {ortho }}\right), 140.49\left(\mathrm{C}_{\text {ortho }}\right), 121.28\left(\mathrm{C}_{\text {para }}\right), 121.17\left(\mathrm{C}_{\text {para }}\right)$, $119.14\left(\mathrm{C}_{\text {meta }}\right), 118.04\left(\mathrm{C}_{\text {meta }}\right), 52.76\left(\mathrm{CH}_{2} \mathrm{CH}_{3}\right), 28.37\left(\mathrm{CHMe}_{2}\right), 27.85\left(\mathrm{CHMe}_{2}\right)$, $24.53(\mathrm{CHMe}), 24.30(\mathrm{CHMe}), 23.64\left(\mathrm{CHMe}_{2}\right), 23.19$ (CHMe $), 14.98\left(\mathrm{CH}_{2} \mathrm{SiMe}_{3}\right)$, $7.33\left(\mathrm{CH}_{2} \mathrm{CH}_{3}\right), 3.06(=\mathrm{CHSiMe}), 2.91\left(\mathrm{CH}_{2} \mathrm{Si} M e_{3}\right) \mathrm{ppm}$.

$\left(\mathbf{E t}_{4} \mathbf{N}\right)\left[(\mathbf{A r N})_{2} \mathbf{C r}(=\mathbf{C H P h})\left(\mathbf{C H}_{2} \mathbf{P h}\right)\right]:(\mathrm{ArN})_{2} \mathrm{Cr}\left(\mathrm{CH}_{2} \mathrm{Ph}\right)_{2}(0.168 \mathrm{~g}, 0.288 \mathrm{mmol})$ was dissolved in $50 \mathrm{~mL}$ THF giving a green brown solution. 1 equiv. of $\mathrm{KN}\left(\mathrm{SiMe}_{3}\right)_{2}$ $(0.058 \mathrm{~g}, 0.288 \mathrm{mmol})$ was added into the solution at room temperature. The solution was stirred for 45 minutes during which time the color changed to red. The solvent was then removed in vacuum and the residue was washed with pentane. Filtering pentane solution would give $\mathrm{K}\left[(\mathrm{ArN}){ }_{2} \mathrm{Cr}(=\mathrm{CHPh})\left(\mathrm{CH}_{2} \mathrm{Ph}\right)\right]$ as powder $(0.144 \mathrm{~g}, 80$ \%). It was then dissolved in THF giving a bright red solution. 1 equiv. of $\mathrm{Et}_{4} \mathrm{NCl}$ $(0.039 \mathrm{~g}, 0.232 \mathrm{mmol})$ was added to red solution at room temperature. The solution was stirred for 4 hours during which time no color change was observed. The solvent was removed in vacuum and the residue was re-dissolved in a small amount of THF. $\mathrm{KCl}$ was removed by filtering the THF solution. Crystalline product was obtained 
from recrystallization by layering the THF solution into pentane (volume ratio $=1: 2$ ) at $-30{ }^{\circ} \mathrm{C}$. Yield: $0.150 \mathrm{~g}, 73 \%$. ${ }^{1} \mathrm{H}$ NMR (400 MHz, THF-d $)$ : $\delta 13.92$ (s, $1 \mathrm{H}$, CHPh), 7.38 (d, 2 H, Ar), 6.96, (t, 2 H, Ar), 6.86 (d, 2 H, Ar), 6.79 (d, 2 H, Ar), 6.76 (d, 2 H, Ar), 6.70 (t, 2 H, Ar), 6.53 (quintet, 3 H, Ar), 6.40 (t, 1 H, Ar), 4.03 (sept, 2 $\mathrm{H}, \mathrm{CHMe}$ ), 3.88 (sept, $2 \mathrm{H}, \mathrm{CHMe}$ ), 3.08 (broad, $8 \mathrm{H}, \mathrm{CH}_{2} \mathrm{CH}_{3} \mathrm{of} \mathrm{Et}_{4} \mathrm{~N}$ ), 2.80 (d, 1 $\left.\mathrm{H}, \mathrm{CH}_{2} \mathrm{Ph}\right), 2.64\left(\mathrm{~d}, 1 \mathrm{H}, \mathrm{CH}_{2} \mathrm{Ph}\right), 1.15$ (broad, $18 \mathrm{H}, \mathrm{CH}_{2} \mathrm{CH}_{3}$ of $\mathrm{Et}_{4} \mathrm{~N}$ and $\mathrm{CHMe}$ ), 1.05 (d, $6 \mathrm{H}, \mathrm{CHMe}$ ), 1.01 (d, $6 \mathrm{H}, \mathrm{CHMe}$ ), 0.97 (d, $6 \mathrm{H}, \mathrm{CHMe}) \mathrm{ppm} .{ }^{13} \mathrm{C}\left\{{ }^{1} \mathrm{H}\right\}$ NMR (150 MHz, THF-d 8 ) $\delta 291.74$ (CHPh), 159.66 (Ar), 158.93 (Ar), 158.36 (Ar), 150.59 (Ar), 142.27 (Ar), 141.48 (Ar), 128.56 (Ar), 127.26 (Ar), 126.86 (Ar), 126.52 (Ar), 122.10 (Ar), 121.54 (Ar), 121.39 (Ar), 119.93 (Ar), 119.06 (Ar), 119.01 (Ar), $52.86\left(\mathrm{CH}_{2} \mathrm{CH}_{3}\right.$ of Et $\left.4 \mathrm{~N}\right), 41.19\left(\mathrm{CH}_{2} \mathrm{Ph}\right), 28.46\left(C \mathrm{HMe}_{2}\right), 28.11\left(C \mathrm{HMe}_{2}\right), 24.11$ (CHMe $), 24.03(\mathrm{CHMe}), 24.00(\mathrm{CHMe}), 23.80(\mathrm{CHMe}), 7.39\left(\mathrm{CH}_{2} \mathrm{CH}_{3}\right.$ of $\left.\mathrm{Et}_{4} \mathrm{~N}\right)$ ppm. IR (KBr, cm $\left.{ }^{-1}\right)$ : 3045 (w), 2957 (m), 2865 (w), 1576 (w), 1483 (m), 1461 (w), 1413 (s), 1392 (w), 1355 (w), 1327 (s), 1279 (s), 1208 (w), $1171(\mathrm{w}), 1096(\mathrm{w}), 980$ (w), $769(\mathrm{w}), 753(\mathrm{~m}), 698(\mathrm{w}), 691(\mathrm{w}) . \mathrm{UV}$-vis (THF): $\lambda_{\max }(\varepsilon)=289\left(1.0^{*} 10^{5}\right)$, $412.5\left(3.9 * 10^{4}\right), 509.5\left(2.1 * 10^{4}\right)\left(\mathrm{M}^{-1} \mathrm{~cm}^{-1}\right)$. Anal. Calcd. for $\mathrm{C}_{46} \mathrm{H}_{67} \mathrm{CrN}_{3}: \mathrm{C}, 77.38 ; \mathrm{H}$, 9.46; N, 5.88. Found: C, 76.59; H, 9.37; N, 5.71. M.P.: $132^{\circ} \mathrm{C}$.

$\mathbf{L i}\left[(\mathbf{A r N})_{2} \mathbf{C r}\left(=\mathbf{C H C M e}_{3}\right)\left(\mathbf{C H}_{2} \mathbf{C M e}_{3}\right)\right]:(\mathrm{ArN})_{2} \mathrm{Cr}\left(\mathrm{CH}_{2} \mathrm{CMe}_{3}\right)_{2}(0.050 \mathrm{~g}, 0.091 \mathrm{mmol})$ was dissolved in $10 \mathrm{~mL}$ THF giving a green solution. The solution was stirred at room temperature for 3 days, during which time color changed from green to red. Then 1 equiv. of $\mathrm{NpLi}(0.18 \mathrm{~mL}, 0.5 \mathrm{M}$ in pentane) was added to the THF solution. The solution was stirred at room temperature for 1 hour. All volatile solvents were removed by vacuum. The residue was washed with pentane and filter to give powder product (0.037 g, 73\%). ${ }^{1} \mathrm{H}$ NMR (400 MHz, THF-d 8 ): $\delta 13.41$ (s, $\left.1 \mathrm{H}, \mathrm{CHCMe}_{3}\right)$, $6.72\left(\mathrm{~d}, 2 \mathrm{H}, \mathrm{H}_{\text {meta }}\right.$ of $\left.\operatorname{ArN}\right), 6.63\left(\mathrm{~d}, 2 \mathrm{H}, \mathrm{H}_{\text {meta }}\right.$ of $\left.\mathrm{ArN}\right), 6.43$ (t, $1 \mathrm{H}, \mathrm{H}_{\text {para }}$ of $\left.\mathrm{ArN}\right)$, 6.35 (t, $1 \mathrm{H}, \mathrm{H}_{\text {para }}$ of ArN), 4.29 (sept, $2 \mathrm{H}, \mathrm{CHMe}$ ), 3.91 (sept, $2 \mathrm{H}, \mathrm{CHMe}$ ), 1.83 (d, $1 \mathrm{H}, \mathrm{CH}_{2} \mathrm{CMe}_{3}$ ), 1.58 (d, $1 \mathrm{H}, \mathrm{CH}_{2} \mathrm{CMe}_{3}$ ), 1.22 (s, $\left.9 \mathrm{H}, \mathrm{CHCMe}_{3}\right), 1.18$ (d, 6H, $\mathrm{CHMe}_{2}$ ), 1.12 (d, 6H, CHMe $), 1.02$ (d, $6 \mathrm{H}, \mathrm{CHMe}$ ), 0.99 (s, $9 \mathrm{H}, \mathrm{CH}_{2} \mathrm{CMe}_{3}$ ), 0.84 $(\mathrm{d}, 6 \mathrm{H}, \mathrm{CHMe} 2) \mathrm{ppm} .{ }^{13} \mathrm{C}\left\{{ }^{1} \mathrm{H}\right\} \mathrm{NMR}\left(100 \mathrm{MHz}, \mathrm{THF}-\mathrm{d}_{8}\right) \delta 306.91\left(\mathrm{CHCMe}_{3}\right)$ 
$159.56\left(\mathrm{C}_{\text {ipso }}\right), 158.98\left(\mathrm{C}_{\text {ipso }}\right), 141.33$ ( $\left.\mathrm{C}_{\text {ortho }}\right), 141.31$ ( $\left.\mathrm{C}_{\text {ortho }}\right), 121.14\left(\mathrm{C}_{\text {para }}\right), 121.04$ $\left(\mathrm{C}_{\text {para }}\right), 118.15\left(\mathrm{C}_{\text {meta }}\right), 117.33\left(\mathrm{C}_{\text {meta }}\right), 51.84\left(\mathrm{CH}_{2} \mathrm{CMe}_{3}\right), 45.58\left(\mathrm{CHCMe}_{3}\right), 35.71$ (CHCMe $), 33.95\left(\mathrm{CH}_{2} \mathrm{CMe}_{3}\right), 32.84\left(\mathrm{CH}_{2} \mathrm{CMe}_{3}\right), 28.40\left(\mathrm{CHMe}_{2}\right), 27.81\left(\mathrm{CHMe}_{2}\right)$, $24.47\left(\mathrm{CHMe}_{2}\right), 24.19\left(\mathrm{CH} M e_{2}\right), 23.70\left(\mathrm{CH} M e_{2}\right), 23.28(\mathrm{CHMe}) \mathrm{ppm}$. IR (KBr, cm $\left.{ }^{1}\right): 2960$ (s), 2868 (m), 1539 (s), 1461 (w), 1323 (w), 1264 (m), 1207 (m), $1174(\mathrm{~m})$, 1045 (m), $1014(\mathrm{w}), 987$ (w), $830(\mathrm{w}), 753$ (w), 513 (m). M.P.: $115^{\circ} \mathrm{C}$.

'[Cr(NAr) $\left.{ }_{2}\right]_{3}$ ': $(\mathrm{ArN})_{2} \mathrm{Cr}\left(\mathrm{CH}_{2} \mathrm{CMe}_{3}\right)_{2}(0.100 \mathrm{~g}, 0.184 \mathrm{mmol})$ was dissolved in $10 \mathrm{~mL}$ cyclohexane giving a green solution. The solution was stirred for 3 days at room temperature during which time color changed to red purple. Cyclohexane was then removed in vacuum and the residue was extracted with pentane. The extract was filtered through Celite. The filtrate was concentrated to $1 \mathrm{~mL}$ then cooled to $-30{ }^{\circ} \mathrm{C}$ overnight to yield red purple crystals. Yield: $0.056 \mathrm{~g}, 76 \%$. ${ }^{1} \mathrm{H}$ NMR (400 MHz, $\mathrm{C}_{6} \mathrm{D}_{6}$ ): $\delta 7.67$ (broad, $2 \mathrm{H}, \mathrm{NHAr}$ ), 7.13-6.77 (Ar), 3.23 (broad, $4 \mathrm{H}, \mathrm{CH}\left(\mathrm{CH}_{2}\right) \mathrm{Me}$ ), 2.62 (sept, $4 \mathrm{H}, \mathrm{CHMe}$ ), 2.32 (sept, $4 \mathrm{H}, \mathrm{CHMe}$ ), 1.87 (broad, $2 \mathrm{H}, \mathrm{CH}\left(\mathrm{CH}_{2}\right) \mathrm{Me}$ ), 1.65 (sept, $4 \mathrm{H}, \mathrm{CHMe}$ ), 1.16 (d, $\left.6 \mathrm{H}, \mathrm{CH}\left(\mathrm{CH}_{2}\right)\left(\mathrm{CH}_{3}\right)\right), 1.09$ (d, $12 \mathrm{H}, \mathrm{CHMe}$ ), 1.08 (d, $12 \mathrm{H}, \mathrm{CHMe}$ ), 0.61 (d, $12 \mathrm{H}, \mathrm{CHMe}$ ), 0.49 (d, $12 \mathrm{H}, \mathrm{CHMe}$ ), 0.37 (d, $12 \mathrm{H}$, $\mathrm{CHMe} 2)$ ppm. ${ }^{13} \mathrm{C}\left\{{ }^{1} \mathrm{H}\right\} \mathrm{NMR}\left(150 \mathrm{MHz}, \mathrm{C}_{6} \mathrm{D}_{6}\right): \delta 169.62\left(\mathrm{C}_{i p s o}\right), 165.10\left(\mathrm{C}_{\text {ipso }}\right)$, $152.90\left(\mathrm{C}_{\text {ipso }}\right), 138.53$ (Ar), 137.32 (Ar), 137.07 (Ar), 134.81 (Ar), 126.07 (Ar), 125.84 (Ar), 124.89 (Ar), 124.22 (Ar), 123.92 (Ar), 123.55 (Ar), 122.11 (Ar), 40.61 $\left(\mathrm{CH}\left(\mathrm{CH}_{2}\right) \mathrm{Me}\right), 29.03\left(\mathrm{CHMe}_{2}\right), 28.35\left(\mathrm{CHMe}_{2}\right), 28.11\left(\mathrm{CHMe}_{2}\right), 27.69\left(\mathrm{CHMe}_{2}\right)$, $24.49(\mathrm{CHMe}), 24.38(\mathrm{CHMe}), 24.10\left(\mathrm{CH}\left(\mathrm{CH}_{2}\right) \mathrm{Me}\right), 23.94\left(\mathrm{CHMe}_{2}\right), 23.53$ (CHMe $), 22.43$ (CHMe $)$, IR (KBr, cm $\left.{ }^{-1}\right): 3340$ (w), 3055 (w), 2960 (s), 2927 (m), $2868(\mathrm{~m}), 2795(\mathrm{w}), 1460(\mathrm{~m}), 1427(\mathrm{w}), 1383(\mathrm{w}), 1361(\mathrm{w}), 1314(\mathrm{w}), 1244(\mathrm{w})$, $1200(\mathrm{w}), 1111(\mathrm{w}), 1045(\mathrm{w}), 1006(\mathrm{w}), 930(\mathrm{w}), 886(\mathrm{w}), 858(\mathrm{w}), 798(\mathrm{w}), 750(\mathrm{~m})$, 658 (w). MS(LIFDI) m/z: 1207.5747 [M+']. Calcd. m/z: 1207.6407 [M+]. M.P.: 176 ${ }^{\circ} \mathrm{C}$.

$(\mathbf{A r N})_{2} \mathbf{C r}\left(\mathbf{P P h}_{3}\right)_{2}$ : Method A: $(\mathrm{ArN})_{2} \mathrm{Cr}\left(\mathrm{CH}_{2} \mathrm{CMe}_{3}\right)_{2}(0.100 \mathrm{~g}, 0.184 \mathrm{mmol})$ was dissolved in $10 \mathrm{~mL}$ cyclohexane giving a green solution. 2 equivalents of $\mathrm{PPh}_{3}(0.096$ 
g, $0.368 \mathrm{mmol}$ ) were added into solution. The solution was stirred for 3 days at room temperature during which time color changed to brown. Cyclohexane was then removed in vacuum and the residue was washed with pentane and filtered. The filter cake was dissolved in $\mathrm{Et}_{2} \mathrm{O}$ and then concentrated to $1 \mathrm{~mL}$. Yellow brown crystals were formed at room temperature in one day. Yield: $0.094 \mathrm{~g}, 55$ \%. Method B: $(\mathrm{ArN})_{2} \mathrm{CrCl}_{2}(0.200 \mathrm{~g}, 0.423 \mathrm{mmol})$ was dissolved in $20 \mathrm{~mL}$ THF giving a red solution. 20 equivalents of magnesium chips $(0.205 \mathrm{~g}, 8.439 \mathrm{mmol})$ and 2 equivalents of $\mathrm{PPh}_{3}(0.222 \mathrm{~g}, 0.846 \mathrm{mmol})$ were added into solution. The solution was stirred for 2 days at room temperature during which time color changed to brown. THF was then removed in vacuum and the residue was washed with pentane and filtered. The filter cake was dissolved in $\mathrm{Et}_{2} \mathrm{O}$ and then concentrated to $1 \mathrm{~mL}$. Yellow brown crystals were formed at room temperature in one day. This synthesis method is modified from a procedure of making $(\mathrm{ArN})_{2} \mathrm{Cr}\left(\mathrm{PMe}_{3}\right)_{2}$, which was reported by Gibson. ${ }^{29}{ }^{1} \mathrm{H} \mathrm{NMR}$ (400 MHz, $\left.\mathrm{C}_{6} \mathrm{D}_{6}\right): \delta 7.48\left(\mathrm{~m}, 12 \mathrm{H}, \mathrm{H}_{\text {ortho }}\right.$ of $\left.\mathrm{PPh}_{3}\right), 7.16\left(\mathrm{H}_{\text {para }}\right.$ of $\mathrm{PPh}_{3}$, overlap with $\left.\mathrm{C}_{6} \mathrm{D}_{6}, \mathrm{ppm}\right), 6.87$ (m, $18 \mathrm{H}, \mathrm{H}_{\text {meta }}$ of $\mathrm{PPh}_{3}$ and $\mathrm{H}$ of $\mathrm{ArN}$ ), 3.98 (br, $4 \mathrm{H}, \mathrm{CHMe}$ ), 0.93 (d, $24 \mathrm{H}, \mathrm{CHMe} 2)$ ppm. ${ }^{13} \mathrm{C}\left\{{ }^{1} \mathrm{H}\right\} \mathrm{NMR}\left(150 \mathrm{MHz}, \mathrm{C}_{6} \mathrm{D}_{6}\right): \delta 160.49\left(\mathrm{C}_{i p s o}\right.$ of $\left.\mathrm{ArN}\right)$, 144.66 ( $\mathrm{C}_{\text {ortho }}$ of $\left.\mathrm{ArN}\right), 137.39\left(\mathrm{C}_{\text {ipso }}\right.$ of $\left.\mathrm{PPh}_{3}\right), 134.60\left(\mathrm{C}_{\text {ortho }}\right.$ of $\left.\mathrm{PPh}_{3}\right), 129.32\left(\mathrm{C}_{\text {meta }}\right.$ of $\left.\mathrm{PPh}_{3}\right), 128.06\left(\mathrm{C}_{\text {meta }}\right.$ of $\mathrm{ArN}$ and $\mathrm{C}_{\text {para }}$ of $\mathrm{ArN}$, overlap with $\left.\mathrm{C}_{6} \mathrm{D}_{6}\right), 123.51\left(\mathrm{C}_{\text {para }}\right.$ of $\left.\mathrm{PPh}_{3}\right), 28.21\left(\mathrm{CHMe}_{2}\right), 24.70\left(\mathrm{CHMe}_{2}\right) \mathrm{ppm} .{ }^{31} \mathrm{P}\left\{{ }^{1} \mathrm{H}\right\} \mathrm{NMR}\left(162 \mathrm{MHz}, \mathrm{C}_{6} \mathrm{D}_{6}\right): \delta$ 102.87 ppm. IR (KBr, cm-1): 3048 (w), 2960 (m), 2924 (w), 2865 (w), 1478 (w), 1458 (w), $1434(\mathrm{~s}), 1416(\mathrm{w}), 1380(\mathrm{w}), 1319(\mathrm{w}), 1264(\mathrm{~s}), 1086(\mathrm{w}), 975(\mathrm{w}), 796(\mathrm{w})$, $747(\mathrm{~m}), 695$ (s), $527(\mathrm{~m}), 517$ (s), 507 (s). UV-vis (THF): $\lambda_{\max }(\varepsilon)=258\left(6.6^{*} 10^{4}\right)$, $421\left(1.1 * 10^{4}\right)\left(\mathrm{M}^{-1} \mathrm{~cm}^{-1}\right)$. Anal. Calcd. for $\mathrm{C}_{60} \mathrm{H}_{64} \mathrm{CrN}_{2} \mathrm{P}_{2}: \mathrm{C}, 77.73 ; \mathrm{H}, 6.96 ; \mathrm{N}, 3.02$. Found: C, 77.72; H, 6.92; N, 2.97. M.P.: $175^{\circ} \mathrm{C}$.

$(\mathbf{A r N})_{2} \mathbf{C r}\left(\mathbf{P P h}_{3}\right)\left(\mathbf{C}_{2} \mathbf{H}_{4}\right):(\mathrm{ArN})_{2} \mathrm{Cr}\left(\mathrm{PPh}_{3}\right)_{2}(10 \mathrm{mg})$ was added into a J-Young tube. Then approximate $0.5 \mathrm{~mL}$ of $\mathrm{C}_{6} \mathrm{D}_{6}$ was added into the tube through vacuum transfer. One atmosphere of ethylene was charged into the tube. A color change from dark brown to light brown was observed immediately. This ethylene adduct was characterized with NMR spectroscopy and LIFDI-MS. ${ }^{1} \mathrm{H}$ NMR (400 MHz, $\left.\mathrm{C}_{6} \mathrm{D}_{6}\right)$ : $\delta$ 
$7.71\left(\mathrm{~m}, 6 \mathrm{H}, \mathrm{H}_{\text {ortho }}\right.$ of $\left.\mathrm{PPh}_{3}\right), 7.05\left(\mathrm{~m}, 13 \mathrm{H}, 3 \mathrm{H}\right.$ from $\mathrm{H}_{\text {para }}$ of free $\mathrm{PPh}_{3}, 6 \mathrm{H}$ from $\mathrm{H}_{\text {meta }}$ of free $\mathrm{PPh}_{3}$ and $4 \mathrm{H}$ from $\mathrm{H}_{\text {meta }}$ of $\left.\mathrm{ArN}\right), 7.01$ (m, $2 \mathrm{H}, \mathrm{H}_{\text {para }}$ of $\left.\mathrm{ArN}\right), 6.96$ (m, 9 $\mathrm{H}, \mathrm{H}_{\text {para }}$ of $\mathrm{PPh}_{3}$ and $\mathrm{H}_{\text {meta }}$ of $\mathrm{PPh}_{3}$ ), 3.88 (sept, $4 \mathrm{H}, \mathrm{CHMe}$ ), 3.12 (t, $2 \mathrm{H}, \mathrm{C}_{2} \mathrm{H}_{4}$, trans to $\mathrm{PPh}_{3}$ ), 2.35 (dt, $2 \mathrm{H}$, cis to $\left.\mathrm{PPh}_{3}\right), 1.09$ (d, $12 \mathrm{H}, \mathrm{CHMe}$ ), 0.98 (d, $12 \mathrm{H}, \mathrm{CHMe}$ ) ppm. ${ }^{13} \mathrm{C}\left\{{ }^{1} \mathrm{H}\right\}$ NMR (150 MHz, $\left.\mathrm{C}_{6} \mathrm{D}_{6}\right): \delta 158.24\left(\mathrm{C}_{\text {ipso }}\right.$ of $\left.\mathrm{ArN}\right), 145.19$ ( $\mathrm{C}_{\text {ortho }}$ of $\operatorname{ArN}), 134.70\left(\mathrm{C}_{\text {ortho }}\right.$ of $\left.\mathrm{PPh}_{3}\right), 133.73\left(\mathrm{C}_{\text {ipso }}\right.$ of $\left.\mathrm{PPh}_{3}\right), 130.20\left(\mathrm{C}_{\text {para }}\right.$ of $\left.\mathrm{PPh}_{3}\right), 128.56$ $\left(\mathrm{C}_{\text {meta }}\right.$ of $\left.\mathrm{PPh}_{3}\right), 124.73\left(\mathrm{C}_{\text {para }}\right.$ of $\left.\mathrm{ArN}\right), 122.75\left(\mathrm{C}_{\text {meta }}\right.$ of $\left.\mathrm{ArN}\right), 58.18\left(\mathrm{~d}, \mathrm{~J}_{\mathrm{PC}}=8.8 \mathrm{~Hz}\right.$, coordinated $\mathrm{C}_{2} \mathrm{H}_{4}$, cis to $\mathrm{PPh}_{3}$ ), 46.98 (s, coordinated $\mathrm{C}_{2} \mathrm{H}_{4}$, trans to $\mathrm{PPh}_{3}$ ), 28.38 $\left(\mathrm{CHMe}_{2}\right), 24.12(\mathrm{CHMe}), 23.86\left(\mathrm{CHMe}_{2}\right) \mathrm{ppm} .{ }^{31} \mathrm{P}\left\{{ }^{1} \mathrm{H}\right\} \mathrm{NMR}\left(162 \mathrm{MHz}, \mathrm{C}_{6} \mathrm{D}_{6}\right): \delta$ 81.82 ppm. MS(LIFDI) m/z: $692.3369\left[\mathrm{M}^{+}\right]$. Calcd. m/z: $692.3351\left[\mathrm{M}^{+}\right]$.

$(\mathbf{A r N})_{2} \mathbf{C r}\left(\mathbf{P P h}_{3}\right)(\mathbf{C O}):(\mathrm{ArN})_{2} \mathrm{Cr}\left(\mathrm{PPh}_{3}\right)_{2}(18 \mathrm{mg})$ was added into a J-Young tube. Then approximate $0.5 \mathrm{~mL}$ of $\mathrm{C}_{6} \mathrm{D}_{6}$ was added into the tube through vacuum transfer. One atmosphere of $\mathrm{CO}$ was charged into the tube. A color change from dark brown to light brown was observed immediately. This carbonyl complex was characterized with NMR spectroscopy and IR spectroscopy. ${ }^{1} \mathrm{H}$ NMR (400 MHz, $\left.\mathrm{C}_{6} \mathrm{D}_{6}\right): \delta 7.62$ (m, $6 \mathrm{H}, \mathrm{H}_{\text {ortho }}$ of $\left.\mathrm{PPh}_{3}\right), 7.05\left(\mathrm{~m}, 6 \mathrm{H}, \mathrm{H}_{\text {meta }}\right.$ of $\left.\mathrm{PPh}_{3}\right), 6.94\left(\mathrm{~m}, 9 \mathrm{H}, \mathrm{H}_{\text {para }}\right.$ of $\mathrm{PPh}_{3}$ and ArN), 3.99 (sept, 4 H, CHMe $), 1.13$ (d, 12 H, CHMe $), 1.08$ (d, 12 H, CHMe $)$ ppm. ${ }^{13} \mathrm{C}\left\{{ }^{1} \mathrm{H}\right\}$ NMR (150 MHz, $\left.\mathrm{C}_{6} \mathrm{D}_{6}\right): \delta 158.41\left(\mathrm{C}_{\text {ipso }}\right.$ of $\left.\mathrm{ArN}\right), 144.93\left(\mathrm{C}_{\text {ortho }}\right.$ of $\left.\mathrm{ArN}\right)$, $134.08\left(\mathrm{~d},{ }^{2} \mathrm{~J}_{\mathrm{PC}}=12.5 \mathrm{~Hz}, \mathrm{C}_{\text {ortho }}\right.$ of $\left.\mathrm{PPh}_{3}\right), 134.08\left(\mathrm{~d},{ }^{1} \mathrm{~J}_{\mathrm{PC}}=40.0 \mathrm{~Hz}, \mathrm{C}_{\text {ipso }} \mathrm{Of} \mathrm{PPh}_{3}\right.$, different coupling constant so it can be assigned), $130.42\left(\mathrm{C}_{\text {para }}\right.$ of $\left.\mathrm{PPh}_{3}\right), 128.82$ $\left(\mathrm{C}_{\text {meta }}\right.$ of $\left.\mathrm{PPh}_{3}\right), 125.30\left(\mathrm{C}_{\text {para }}\right.$ of $\left.\mathrm{ArN}\right), 122.74\left(\mathrm{C}_{\text {meta }}\right.$ of $\left.\mathrm{ArN}\right), 28.60\left(\mathrm{CHMe}_{2}\right), 23.68$ $\left(\mathrm{CHMe}_{2}\right), 23.32(\mathrm{CHMe}) \mathrm{ppm} .{ }^{31} \mathrm{P}\left\{{ }^{1} \mathrm{H}\right\} \mathrm{NMR}\left(162 \mathrm{MHz}, \mathrm{C}_{6} \mathrm{D}_{6}\right): \delta 84.38 \mathrm{ppm}$. IR (KBr, cm$\left.{ }^{-1}\right)$ : 3052(w), $2961(\mathrm{~m}), 2922(\mathrm{w}), 2867(\mathrm{w}), 1932(\mathrm{~s}), 1479(\mathrm{w}), 1458(\mathrm{w})$, 1435 (m), 1377 (w), 1361 (w), 1326 (w), 1279 (w), 1182 (w), $1094(w), 797(w), 745$ (m), $695(\mathrm{~m}), 529(\mathrm{w}), 503(\mathrm{w})$.

$(\mathbf{A r N}) \mathbf{C r}\left(\mathbf{P P h}_{3}\right)(\mathbf{C O})_{3}$ : Let the NMR tube of making $(\mathrm{ArN})_{2} \mathrm{Cr}\left(\mathrm{PPh}_{3}\right)(\mathrm{CO})$ stand at room temperature for 7 days. Solution color changed from light brown to yellowbrown slowly. NMR showed that most $(\mathrm{ArN})_{2} \mathrm{Cr}\left(\mathrm{PPh}_{3}\right)(\mathrm{CO})$ decomposed to 
$(\mathrm{ArN}) \mathrm{Cr}\left(\mathrm{PPh}_{3}\right)(\mathrm{CO})_{3}$ and small amount of $(\mathrm{ArN}) \mathrm{Cr}\left(\mathrm{PPh}_{3}\right)_{2}(\mathrm{CO})_{2}$. Small amount of $(\mathrm{ArN}) \mathrm{Cr}\left(\mathrm{PPh}_{3}\right)_{2}(\mathrm{CO})_{2}$ was confirmed by NMR and LIFDI-MS. ${ }^{1} \mathrm{H}$ NMR (400 MHz, $\left.\mathrm{C}_{6} \mathrm{D}_{6}\right): \delta 7.82\left(\mathrm{~m}, 6 \mathrm{H}, \mathrm{PPh}_{3}\right), 7.05-6.89\left(\mathrm{~m}, 12 \mathrm{H}, \mathrm{PPh}_{3}\right.$ and $\mathrm{ArN}$, overlapped with ArNCO, $\left.\mathrm{PPh}_{3}\right), 4.06$ (sept, $2 \mathrm{H}, \mathrm{CHMe}$ ), 1.17 (d, $\left.12 \mathrm{H}, \mathrm{CHMe} 2\right) \mathrm{ppm} .{ }^{31} \mathrm{P}\left\{{ }^{1} \mathrm{H}\right\} \mathrm{NMR}$ $\left(162 \mathrm{MHz}, \mathrm{C}_{6} \mathrm{D}_{6}\right): \delta 72.65$ ppm. MS(LIFDI) m/z: $573.1534\left[\mathrm{M}^{+}\right]$. Calcd. m/z: $573.1525\left[\mathrm{M}^{+}\right]$.

$(\mathbf{A r N}) \mathbf{C r}\left(\mathbf{P P h}_{3}\right)_{2}(\mathbf{C O})_{2}$ : Let the NMR tube of making $(\mathrm{ArN})_{2} \mathrm{Cr}\left(\mathrm{PPh}_{3}\right)(\mathrm{CO})$ stand at room temperature for 18 days. Solution color changed from light brown to yellowgreen slowly. The solvent was then removed in vacuum and the residue was washed with pentane and then extracted with $\mathrm{Et}_{2} \mathrm{O}$. The extract was filtered through Celite and the filtrate was concentrated to $0.5 \mathrm{~mL}$ then cooled to $-30{ }^{\circ} \mathrm{C}$ overnight to yield yellow-green crystals. Single crystals for structural characterization was grown from slow evaporation of ether solution at room temperature. ${ }^{1} \mathrm{H}$ NMR (400 MHz, $\left.\mathrm{C}_{6} \mathrm{D}_{6}\right)$ : $\delta$ $7.82\left(\mathrm{~m}, 12 \mathrm{H}, \mathrm{PPh}_{3}\right), 7.03$ (m, 18H, $\left.\mathrm{PPh}_{3}\right), 6.93$ (m, $\left.3 \mathrm{H}, \mathrm{ArN}\right), 4.21$ (sept, $2 \mathrm{H}$, $\left.\mathrm{CHMe}_{2}\right), 0.99$ (d, $\left.12 \mathrm{H}, \mathrm{CHMe} 2\right) \mathrm{ppm} .{ }^{13} \mathrm{C}\left\{{ }^{1} \mathrm{H}\right\} \mathrm{NMR}\left(150 \mathrm{MHz}, \mathrm{C}_{6} \mathrm{D}_{6}\right): \delta 261.91(\mathrm{t}$, $\left.{ }^{2} \mathrm{~J}_{\mathrm{PC}}=34.0 \mathrm{~Hz}, \mathrm{CO}\right), 155.19\left(\mathrm{C}_{\text {ipso }}\right.$ of $\left.\mathrm{ArN}\right), 150.23\left(\mathrm{C}_{\text {ortho }}\right.$ of $\left.\mathrm{ArN}\right), 137.50\left(\mathrm{C}_{\text {ipso }}\right.$ of $\left.\mathrm{PPh}_{3}\right), 134.18\left(\mathrm{C}_{\text {ortho }}\right.$ of $\left.\mathrm{PPh}_{3}\right), 129.77\left(\mathrm{C}_{\text {para }}\right.$ of $\left.\mathrm{PPh}_{3}\right), 128.39\left(\mathrm{C}_{\text {meta }}\right.$ of $\left.\mathrm{PPh}_{3}\right), 27.47$ $\left(\mathrm{CHMe}_{2}\right), 24.41(\mathrm{CHMe})$ ppm. ${ }^{31} \mathrm{P}\left\{{ }^{1} \mathrm{H}\right\} \mathrm{NMR}\left(162 \mathrm{MHz}, \mathrm{C}_{6} \mathrm{D}_{6}\right): \delta 89.73 \mathrm{ppm}$.

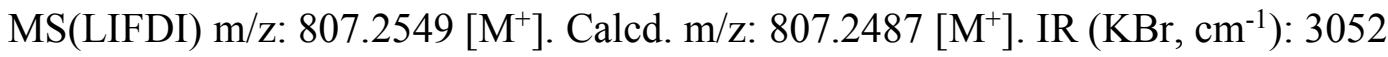
(w), $2961(\mathrm{w}), 2866(\mathrm{w}), 1900$ (s), 1800 (s), $1480(\mathrm{w}), 1434$ (m), 1089 (w), 743 (w), $695(\mathrm{~m}), 642(\mathrm{w}), 619(\mathrm{w}), 572(\mathrm{w}), 541(\mathrm{w}), 515(\mathrm{~m})$.

\section{X-ray structural analyses for $\mathrm{Et}_{4} \mathrm{~N}\left[(\mathrm{ArN})_{2} \mathrm{Cr}\left(=\mathrm{CHSiMe}_{3}\right)\left(\mathrm{CH}_{2} \mathrm{SiMe}_{3}\right)\right]$,} '[Cr(NAr $\left.)_{2}\right]_{3}$ ', $(\mathbf{A r N})_{2} \mathbf{C r}\left(\mathbf{P P h}_{3}\right)_{2}$, and $(\operatorname{ArN}) \mathbf{C r}\left(\mathbf{P P h}_{3}\right)_{2}(\mathbf{C O})_{2}$ : Crystals were mounted using viscous oil onto a plastic mesh and cooled to the data collection temperature. Data were collected on a Bruker-AXS APEX II DUO CCD diffractometer with graphite monochromated Mo-K $\alpha$ radiation $(\lambda=0.71073 \quad \AA)$ for $\mathrm{Et}_{4} \mathrm{~N}\left[(\mathrm{ArN})_{2} \mathrm{Cr}\left(=\mathrm{CHSiMe}_{3}\right)\left(\mathrm{CH}_{2} \mathrm{SiMe}_{3}\right)\right]$ and with $\mathrm{Cu}-\mathrm{K} \alpha$ radiation $(\lambda=1.54178 \AA)$ focused with Goebel mirrors for the other samples. Unit cell parameters were obtained 
from 36 data frames, $0.5^{\circ} \omega$, from three different sections of the Ewald sphere. ${ }^{30}$ The systematic absences in the diffraction data are consistent, uniquely, with $P-42{ }_{1} c$ (114) for $\mathrm{Et}_{4} \mathrm{~N}\left[(\mathrm{ArN})_{2} \mathrm{Cr}\left(=\mathrm{CHSiMe}_{3}\right)\left(\mathrm{CH}_{2} \mathrm{SiMe}_{3}\right)\right] ; \quad R 3 c \quad$ (161) and $R-3 c$ (167) for '[Cr(NAr $\left.)_{2}\right]_{3}$ '; uniquely with $\mathrm{Pbcn}(60)$ for $(\mathrm{ArN})_{2} \mathrm{Cr}\left(\mathrm{PPh}_{3}\right)_{2}$; and uniquely with $P 2_{1} / c$ (14) for $(\mathrm{ArN}) \mathrm{Cr}\left(\mathrm{PPh}_{3}\right)_{2}(\mathrm{CO})_{2}$. Solution in the centrosymmetric option, $R-3 c$ (167) for ' $\left[\mathrm{Cr}(\mathrm{NAr})_{2}\right]_{3}$ ' yielded chemically reasonable and computationally stable results of refinement. The data were treated with multi-scan absorption corrections. The structures were solved using intrinsic phasing methods ${ }^{31}$ and refined with full-matrix, least-squares procedures on $F^{2} \cdot{ }^{32}$ Crystallographic data and refinement details are listed in Table 1.

The alkyl and alkylidene moieties in $\mathrm{Et}_{4} \mathrm{~N}\left[(\mathrm{ArN})_{2} \mathrm{Cr}\left(=\mathrm{CHSiMe}_{3}\right)\left(\mathrm{CH}_{2} \mathrm{SiMe}_{3}\right)\right]$, were found to be disordered with respect to each other with a refined site occupancy of 64/36. Chemically equivalent, non-coincident atom positions of the disordered model were restrained with similar bond metrics and equivalent displacement parameters.

The trinuclear ' $\left[\mathrm{Cr}(\mathrm{NAr})_{2}\right]_{3}$ ', was found to have a minor disordered component that was located slightly off the $2 / \mathrm{m}$ axis of the major component with a refined disordered site occupancy of 91/9. However, because of the slight contribution, only one minor component of a chromium atom could be located and modeled. The entire disordered structure was treated with global three-dimensional, rigid-bond displacement restraints. Residual electron density was treated as diffused contributions. ${ }^{33}$

Two symmetry-unique but chemically-equivalent compound molecules were found in the asymmetric unit of $(\mathrm{ArN}) \mathrm{Cr}\left(\mathrm{PPh}_{3}\right)_{2}(\mathrm{CO})_{2}$.

Non-hydrogen atoms were refined with anisotropic displacement parameters. H-atoms were treated as idealized contributions with geometrically calculated positions and with $U_{i s o}$ equal to $1.2 U_{e q}\left(1.5 U_{e q}\right.$ for methyl) of the attached atom. Atomic scattering factors are contained in the SHELXTL program library. ${ }^{32}$ The structures have been 
deposited at the Cambridge Structural Database under the following depositary numbers: CCDC 1892718-1892721.

Table 1. Crystallographic data and refinement details for $\mathrm{NEt}_{4}\left[(\mathrm{ArN})_{2} \mathrm{Cr}\left(=\mathrm{CHSiMe}_{3}\right)\left(\mathrm{CH}_{2} \mathrm{SiMe}_{3}\right)\right]$, ' $[\mathrm{Cr}(\mathrm{NAr}) 2] 3$ ', and $(\mathrm{ArN})_{2} \mathrm{Cr}\left(\mathrm{PPh}_{3}\right)_{2}$.

\begin{tabular}{|c|c|c|c|}
\hline & $\begin{array}{c}\mathrm{NEt}_{4}\left[(\mathrm{ArN})_{2} \mathrm{Cr}\right. \\
\left.\left(\mathrm{CHSiMe}_{3}\right)\left(\mathrm{CH}_{2} \mathrm{SiMe}_{3}\right)\right]\end{array}$ & ' $\left[\mathrm{Cr}(\mathrm{NAr})_{2}\right]_{3}{ }^{\prime}$ & $(\mathrm{ArN})_{2} \mathrm{Cr}\left(\mathrm{PPh}_{3}\right)_{2}$ \\
\hline formula & $\mathrm{C}_{40} \mathrm{H}_{75} \mathrm{CrN}_{3} \mathrm{Si}_{2}$ & $\mathrm{C}_{72} \mathrm{H}_{102} \mathrm{Cr}_{3} \mathrm{~N}_{6}$ & $\mathrm{C}_{60} \mathrm{H}_{64} \mathrm{CrN}_{2} \mathrm{P}_{2}$ \\
\hline fw & 706.21 & 1207.59 & 927.07 \\
\hline space group & $\mathrm{P}-42{ }_{1} / \mathrm{c}$ & $\mathrm{R}-3 \mathrm{c}$ & $P b c n$ \\
\hline color & red & brown & brown \\
\hline $\mathrm{a}, \AA$ & $21.9368(13)$ & $26.3427(6)$ & $13.9462(5)$ \\
\hline $\mathrm{b}, \AA$ & $21.9368(13)$ & $26.3427(6)$ & $17.9775(6)$ \\
\hline $\mathrm{c}, \AA$ & $19.1573(11)$ & $71.6398(17)$ & $20.6293(7)$ \\
\hline$\alpha,^{\circ}$ & 90 & 90 & 90 \\
\hline$\beta, \circ$ & 90 & 90 & 90 \\
\hline$\gamma,^{\circ}$ & 90 & 120 & 90 \\
\hline $\mathrm{V}, \AA^{3}$ & $9218.9(12)$ & $43053(2)$ & $5172.1(3)$ \\
\hline $\mathrm{Z}, \mathrm{Z}^{\prime}$ & 8,1 & 18,1 & 4 \\
\hline $\mathrm{D}_{\text {(calcd) }}, \mathrm{g} \mathrm{cm}^{-3}$ & 1.018 & 0.838 & 1.191 \\
\hline$\mu, \mathrm{mm}^{-1}$ & 0.327 & 2.988 & 2.695 \\
\hline$\lambda, \AA$ & 0.71073 & 1.54178 & 1.54178 \\
\hline Temp, K & $200(2)$ & $200(2)$ & $200(2)$ \\
\hline data/params & $10454 / 448$ & $9830 / 381$ & $5323 / 298$ \\
\hline GOF on $\mathrm{F}^{2}$ & 1.030 & 1.056 & 1.044 \\
\hline $\mathrm{R}(\mathrm{F}), \%$ & 6.52 & 6.47 & 3.30 \\
\hline $\mathrm{R}_{\mathrm{w}}\left(\mathrm{F}^{2}\right), \%$ & 15.67 & 19.32 & 8.95 \\
\hline Flack param & $-0.012(14)$ & --- & --- \\
\hline
\end{tabular}

Quantity minimized: $\mathrm{R}_{\mathrm{w}}\left(\mathrm{F}^{2}\right)=\Sigma\left[\mathrm{w}\left(\mathrm{F}_{\mathrm{o}}{ }^{2}-\mathrm{F}_{\mathrm{c}}{ }^{2}\right)^{2}\right] / \Sigma\left[\left(\mathrm{wF}_{\mathrm{o}}{ }^{2}\right)^{2}\right]^{1 / 2}$

\section{Author Information}

\section{Corresponding Author}

theopold@udel.edu

ORCID:

Klaus H. Theopold: 0000-0001-5168-1625

Glenn P. A. Yap: 0000-0003-0385-387X 
Notes: The authors declare no competing financial interest.

The Supporting Information contains details of the molecular structure determination by X-ray diffraction of $(\mathrm{ArN}) \mathrm{Cr}\left(\mathrm{PPh}_{3}\right)_{2}(\mathrm{CO})_{2}$.

\section{Acknowledgment}

We gratefully acknowledge NSF (CHE-1565955) for funding. Support for shared instrumentation was provided by NSF (CHE-1048367 and CHE-0840401) and NIH (P20GM104316, P30GM110758, S10RR026962-01).

\section{References}

1. Schrock, R. R., Alkylcarbene Complex of Tantalum by Intramolecular AlphaHydrogen Abstraction. J. Am. Chem. Soc. 1974, 96 (21), 6796-6797.

2. Delaude, L.; Noels, A. F., Metathesis. In Kirk-Othmer Encyclopedia of Chemical Technology.

3. Wengrovius, J. H.; Schrock, R. R.; Churchill, M. R.; Missert, J. R.; Youngs, W. J., Multiple Metal-Carbon Bonds .16. Tungsten-Oxo Alkylidene Complexes as Olefin Metathesis Catalysts and the Crystal-Structure of $\mathrm{W}(\mathrm{O})\left(\mathrm{CHCMe}_{3}\right)\left(\mathrm{PEt}_{3}\right) \mathrm{Cl}_{2} . \mathrm{J} . \mathrm{Am}$. Chem. Soc. 1980, 102 (13), 4515-4516.

4. Schrock, R. R.; Murdzek, J. S.; Bazan, G. C.; Robbins, J.; Dimare, M.; Oregan, M., Synthesis of Molybdenum Imido Alkylidene Complexes and Some Reactions Involving Acyclic Olefins. J. Am. Chem. Soc. 1990, 112 (10), 3875-3886.

5. Bazan, G. C.; Oskam, J. H.; Cho, H. N.; Park, L. Y.; Schrock, R. R., Living RingOpening Metathesis Polymerization of 2,3-Difunctionalized 7-Oxanorbornenes and 7Oxanorbornadienes by $\mathrm{Mo}\left(\mathrm{CHCMe}_{2} \mathrm{R}\right)\left(\mathrm{N}-2,6-\mathrm{C}_{6} \mathrm{H}_{3}\right.$-iso- $\left.\mathrm{Pr}_{2}\right)(\mathrm{O}-\text { tert-Bu})_{2}$ and $\mathrm{Mo}\left(\mathrm{CHCMe}_{2} \mathrm{R}\right)\left(\mathrm{N}-2,6-\mathrm{C}_{6} \mathrm{H}_{3}\right.$ iso- $\left.\mathrm{Pr}_{2}\right)\left(\mathrm{OCMe}_{2} \mathrm{CF}_{3}\right)_{2}$. J. Am. Chem. Soc. 1991, 113 (18), 6899-6907.

6. Schrock, R. R., High oxidation state multiple metal-carbon bonds. Chem. Rev. 2002, 102 (1), 145-179.

7. Coles, M. P.; Gibson, V. C.; Clegg, W.; Elsegood, M. R. J.; Porrelli, P. A., Synthesis and reactivity of the first stable chromium(VI) alkylidene complexes. Chem. Commun. 1996, (16), 1963-1964.

8. Noh, S. K.; Heintz, R. A.; Theopold, K. H., Deprotonation of Bis(Dimethylphosphino)Ethane Ligand of a Cationic Chromium Alkyl. Organometallics 1989, 8 (8), 2071-2073.

9. Bhandari, G.; Kim, Y. Y.; Mcfarland, J. M.; Rheingold, A. L.; Theopold, K. H., Paramagnetic (Benzyl)Chromium Complexes as Homogeneous Ethylene Polymerization Catalysts. Organometallics 1995, 14 (2), 738-745. 
10. Heintz, R. A.; Leelasubcharoen, S.; Liable-Sands, L. M.; Rheingold, A. L.; Theopold, K. H., Structure and Reactivity of Trimethylsilylmethyl Complexes of Chromium, Including the 13-Electron Alkyl $\mathrm{Cp} * \mathrm{Cr}\left(\mathrm{CH}_{2} \mathrm{SiMe}_{3}\right)_{2}$. Organometallics 1998, 17 (25), 5477-5485.

11. Wu, P. C.; Yap, G. P. A.; Theopold, K. H., Structure and Reactivity of Chromium(VI) Alkylidenes. J. Am. Chem. Soc. 2018, 140 (23), 7088-7091.

12. Schrock, R. R.; Sharp, P. R., Multiple Metal-Carbon Bonds .7. Preparation and Characterization of $\mathrm{Ta}\left(\eta^{5}-\mathrm{C}_{5} \mathrm{H}_{5}\right)_{2}\left(\mathrm{CH}_{2}\right)\left(\mathrm{CH}_{3}\right)$, a Study of Its Decomposition, and Some Simple Reactions. J. Am. Chem. Soc. 1978, 100 (8), 2389-2399.

13. Fraser, R. R.; Mansour, T. S.; Savard, S., Acidity Measurements on Pyridines in Tetrahydrofuran Using Lithiated Silylamines. J. Org. Chem. 1985, 50 (17), 3232-3234. 14. Yang, L.; Powell, D. R.; Houser, R. P., Structural variation in copper(I) complexes with pyridylmethylamide ligands: structural analysis with a new four-coordinate geometry index, tau(4). Dalton Trans. 2007, (9), 955-964.

15. Coles, M. P.; Dalby, C. I.; Gibson, V. C.; Clegg, W.; Elsegood, M. R. J., WellDefined Ethylene Polymerization Catalysts Derived from Bis(Imido) Chromium(VI) Precursors. J. Chem. Soc., Chem. Commun. 1995, (16), 1709-1711.

16. Coles, M. P.; Dalby, C. I.; Gibson, V. C.; Clegg, W.; Elsegood, M. R. J., Bis(Arylimido) Complexes of Chromium(VI). Polyhedron 1995, 14 (17-18), 24552459.

17. Hursthouse, M. B.; Motevalli, M.; Sullivan, A. C.; Wilkinson, G., Synthesis and $\mathrm{X}$-Ray Crystal-Structure of an Arylchromium(VI) Derivative (Butn) ${ }_{2} \mathrm{Cr}(2,4,6-$ $\left.\mathrm{Me}_{3} \mathrm{C}_{6} \mathrm{H}_{2}\right)_{2}$. J. Chem. Soc., Chem. Commun. 1986, (18), 1398-1399.

18. Leung, W. H.; Danopoulos, A. A.; Wilkinson, G.; Hussainbates, B.; Hursthouse, M. B., Tert-Butylimido Complexes of Chromium and Vanadium - X-Ray CrystalStructures of $\mathrm{Cr}\left(\mathrm{N}^{t} \mathrm{Bu}\right) \mathrm{Cl}_{3}\left(\mathrm{MeOCH}_{2} \mathrm{CH}_{2} \mathrm{OMe}\right), \mathrm{Cr}\left[\mathrm{C}_{6} \mathrm{H}_{4}(\mathrm{NH})_{2}\right.$-ortho $] \mathrm{Cl}_{2}\left(\mathrm{PMe}_{2} \mathrm{Ph}\right)_{2}$, $\mathrm{Cr}\left(\mathrm{N}^{t} \mathrm{Bu}\right)_{2}\left(\mathrm{OSiPh}_{3}\right)_{2}, \mathrm{Cr}\left(\mathrm{N}^{t} \mathrm{Bu}\right) \mathrm{Cl}\left(\mathrm{OC}_{9} \mathrm{H}_{6} \mathrm{~N}\right)_{2}$ and $\left[\left(\mathrm{PPh}_{3}\right)_{2}\right]\left[\mathrm{Cr}\left(\mathrm{N}^{t} \mathrm{Bu}\right)\left(\mathrm{S}_{2} \mathrm{C}_{2}(\mathrm{CN})_{2}\right)_{2}\right] . J$. Chem. Soc., Dalton Trans. 1991, (8), 2051-2061.

19. Lam, H. W.; Wilkinson, G.; Hussainbates, B.; Hursthouse, M. B., Reactions of Tert-Butyl Isocyanate and Trimethylsilyl Azide with Imidoamido Compounds of Chromium, Molybdenum and Tungsten. J. Chem. Soc., Dalton Trans. 1993, (5), 781788.

20. Lam, H. W.; Wilkinson, G.; Hussainbates, B.; Hursthouse, M. B., Imido and Oxo Compounds of Chromium-(V) and Chromium-(VI) and of Molybdenum-(VI) and Tungsten-(VI). J. Chem. Soc., Dalton Trans. 1993, (10), 1477-1482.

21. Janiak, C., A critical account on $\pi-\pi$ stacking in metal complexes with aromatic nitrogen-containing ligands $\uparrow$. Journal of the Chemical Society, Dalton Transactions 2000, (21), 3885-3896.

22. Martinez, C. R.; Iverson, B. L., Rethinking the term "pi-stacking". Chemical Science 2012, 3 (7), 2191-2201.

23. Chew, K. C.; Clegg, W.; Coles, M. P.; Elsegood, M. R. J.; Gibson, V. C.; White, A. J. P.; Williams, D. J., Synthesis and characterisation of 2,6-diisopropylphenylimido complexes of chromium in oxidation states IV-VI. J. Chem. Soc., Dalton Trans. 1999, (15), 2633-2639. 
24. Gibson, V. C., A journey in metal-ligand multiple bond chemistry. In Modern Coordination Chemistry: The Legacy of Joseph Chatt, Winterton, N.; Leigh, J., Eds. The Royal Society of Chemistry: 2002; pp 140 - 153.

25. Albright, T. A.; Burdett, J. K.; Whangbo, M. H., Orbital Interactions in Chemistry. 2nd ed.; Joihn Wiley \& Sons: Hoboken, 2013.

26. Sinnema, P. J.; Nairn, J.; Zehnder, R.; Shapiro, P. J.; Twamley, B.; Blumenfeld, A., Isolation and structural characterization of the first thermally robust and air stable $\mathrm{Cr}(4+)$ bent-metallocene complex. Chem. Commun. 2004, (1), 110-111.

27. Coles, M. P.; Dalby, C. I.; Gibson, V. C.; Little, I. R.; Marshall, E. L.; da Costa, M. H. R.; Mastroianni, S., Transition metal imido catalysts for ethylene polymerisation. $J$. Organomet. Chem. 1999, 591 (1-2), 78-87.

28. Linden, H. B., Liquid injection field desorption ionization: a new tool for soft ionization of samples including air-sensitive catalysts and non-polar hydrocarbons. Eur. J. Mass Spectrom. 2004, 10 (4), 459-468.

29. Chew, K. C.; Clegg, W.; Coles, M. P.; Elsegood, M. R. J.; Gibson, V. C.; White, A. J. P.; Williams, D. J., Synthesis and characterisation of 2,6-diisopropylphenylimido complexes of chromium in oxidation states IV-VI. Journal of the Chemical Society, Dalton Transactions 1999, (15), 2633-2640.

30. Apex3; Bruker AXS Inc.: Madison, WI, 2015.

31. Sheldrick, G. M., SHELXT - Integrated space-group and crystal-structure determination. Acta Crystallogr A 2015, A71, 3-8.

32. Sheldrick, G. M., Crystal structure refinement with SHELXL. Acta Crystallogr $C$ 2015, 71, 3-8.

33. Spek, A. L., PLATON SQUEEZE: a tool for the calculation of the disordered solvent contribution to the calculated structure factors. Acta Crystallogr C 2015, 71, 918 . 